
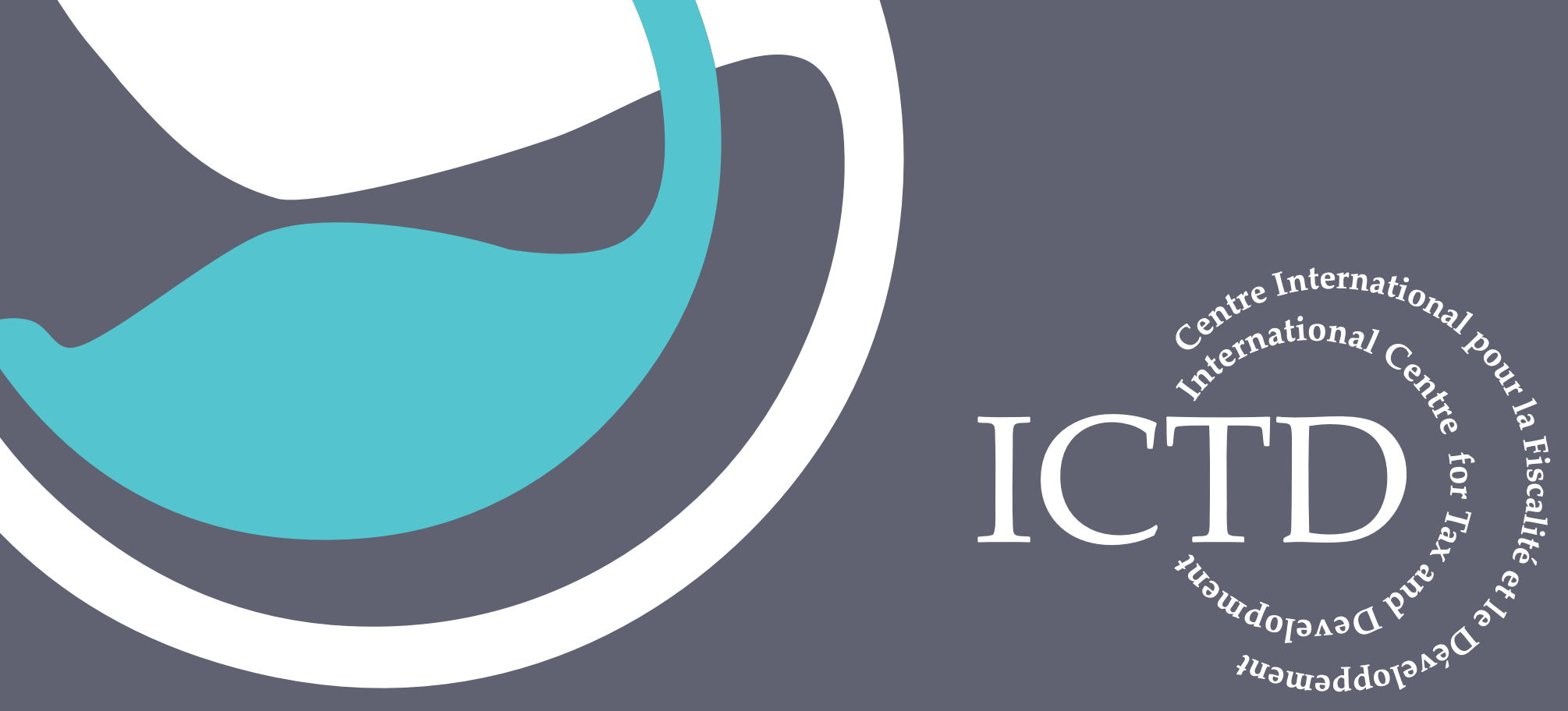

Working Paper 49

\title{
A Fiscal History of Fthiopia: Taxation and Aid Dependence 1960-2010
}

Giulia Mascagni

March 2016 
ICTD Working Paper 49

\section{A Fiscal History of Ethiopia: Taxation and Aid Dependence 1960-2010}

Giulia Mascagni

March 2016 
A Fiscal History of Ethiopia: Taxation and Aid Dependence 1960-2010

Giulia Mascagni

ICTD Working Paper 49

First published by the Institute of Development Studies in March 2016

(C) Institute of Development Studies 2016

ISBN: 978-1-78118-294-9

A catalogue record for this publication is available from the British Library.

All rights reserved. Reproduction, copy, transmission, or translation of any part of this publication may

be made only under the following conditions:

- with the prior permission of the publisher; or

- with a licence from the Copyright Licensing Agency Ltd., 90 Tottenham Court Road, London W1P 9HE, UK,

or from another national licensing agency; or

- under the terms set out below.

This publication is copyright, but may be reproduced by any method without fee for teaching or nonprofit purposes, but not for resale. Formal permission is required for all such uses, but normally will be granted immediately. For copying in any other circumstances, or for reuse in other publications, or for translation or adaptation, prior written permission must be obtained from the publisher and a fee may be payable.

Available from:

The International Centre for Tax and Development

at the Institute of Development Studies,

Brighton BN1 9RE, UK

Tel: +44 (0) 1273606261 Fax: +44 (0) 1273621202

E-mail: info@ictd.ac.uk

Web: www.ictd/en/publications

IDS is a charitable company limited by guarantee and registered in England (No. 877338) 


\title{
A Fiscal History of Ethiopia: Taxation and Aid Dependence 1960-2010
}

\author{
Giulia Mascagni
}

\section{Summary}

This paper reviews the fiscal history of Ethiopia, focusing particularly on the period between 1960 and 2010, for which detailed fiscal data is available to underpin the analysis. While reviewing the key fiscal and economic events of this period, particular attention is paid to the relation between Ethiopia and its donors, which in fiscal terms can be seen as a relation between mobilising own tax revenue while negotiating aid and the conditions attached to it. While looking at the main drivers and constraints to tax revenue mobilisation in this period, the paper explores the role that aid and donors have played, and how this historical background influences Ethiopia today.

Keywords: fiscal history; Ethiopia; taxation; aid.

Giulia Mascagni is a Research Fellow at the Institute of Development Studies (IDS), and Capacity Building Manager at the International Centre for Tax and Development (ICTD). 


\section{Contents}

Summary 3

Acknowledgements $\quad 5$

Acronyms 5

$1 \quad$ Introduction $\quad 6$

2 Methodology 7

$3 \quad$ The Imperial period: 1941-1974 8

3.1 Taxation in the agricultural sector 8

3.2 Other taxes: trade, consumption and the industrial sector 10

3.3 Increasing revenue needs and development planning 11

$\begin{array}{lll}3.4 & \text { Borrowing and external assistance } & 12\end{array}$

3.5 Opposition movements and the decline of the regime 14

$4 \quad$ The Derg: 1974-1991 15

4.1 The revolution and its opponents 15

$\begin{array}{lll}4.2 & \text { External relations and aid } & 18\end{array}$

$\begin{array}{lll}4.3 & \text { Fiscal trends } & 19\end{array}$

$5 \quad$ The Ethiopian People's Revolutionary Democratic Front: 1991-2010 21

5.1 Transition and ethnic federalism: 1991-1998 21

5.2 Economic policies in the 1990s 23

5.3 The war with Eritrea and the TPLF crisis: 1998-2002 24

$\begin{array}{ll}5.4 & \text { Consolidation and reform } \\ 5.5 & 25\end{array}$

5.5 External relations 28

5.6 Tax revenue mobilisation 30

$6 \quad$ Implications for tax and aid: four underlying factors 33

$\begin{array}{lll}7 & \text { Conclusion } & 38\end{array}$

$\begin{array}{ll}\text { References } & 39\end{array}$

Tables

Table 1 Selected indicators averaged by political era

Figures

Figure 1

Figure 2

Composition of domestic revenue 9

$\begin{array}{lll}\text { Figure } 3 & \text { Budget deficit as a share of GDP } & 13\end{array}$

$\begin{array}{lll}\text { Figure } 4 & \text { GDP per capita at constant prices } & 17\end{array}$

Figure $5 \quad$ Trends in fiscal variables $\quad 20$

Figure $6 \quad$ Deviations from three-year moving average of grants and tax 24

Figure $7 \quad$ Growth rate of GDP at constant prices 27

Figure $8 \quad$ Aid dependency: grants and loans as a share of total expenditure 28 


\section{Acknowledgements}

I am particularly grateful to the Ethiopian Development Research Institute (EDRI) for offering a base during my time in Ethiopia and for facilitating my fieldwork, and to the Ministry of Finance and Economic Development (MOFED) for providing the macroeconomic data and other supporting information. I owe special thanks to those who agreed to be interviewed, and those who provided comments on earlier versions of this paper. Last but not least, I am grateful to the International Centre for Tax and Development (ICTD) for supporting the publication of this paper.

\section{Acronyms}

$\begin{array}{ll}\text { ADLI } & \text { Agricultural Development Led Industrialization } \\ \text { CELU } & \text { Confederation of Ethiopian Labor Unions } \\ \text { COPWE } & \text { Committee for Organizing the Party of the Workers of Ethiopia } \\ \text { CSO } & \text { Central Statistical Office } \\ \text { DFID } & \text { Department for International Development } \\ \text { EDRI } & \text { Ethiopian Development Research Institute } \\ \text { EPLF } & \text { Eritrean People's Liberation Front } \\ \text { EPRDF } & \text { Ethiopian People's Revolutionary Democratic Front } \\ \text { EPRP } & \text { Ethiopian People's Revolutionary Party } \\ \text { ERCA } & \text { Ethiopian Revenue and Customs Authority } \\ \text { GTP } & \text { Growth and Transformation Plan } \\ \text { IFI } & \text { International Finance Institution } \\ \text { IMF } & \text { International Monetary Fund } \\ \text { MCC } & \text { Military Coordinating Committee } \\ \text { MOFED } & \text { Ministry of Finance and Economic Development } \\ \text { NBE } & \text { National Bank of Ethiopia } \\ \text { OAU } & \text { Organization of the African Union } \\ \text { ONCCP } & \text { Office of the National Committee for Central Planning } \\ \text { PA } & \text { Peasant Association } \\ \text { PASDEP } & \text { Plan for Accelerated and Sustained Development to End Poverty } \\ \text { PBS } & \text { Protection of Basic Services } \\ \text { PMG } & \text { Provisional Military Government } \\ \text { PSCAP } & \text { Public Sector Capacity Building Program } \\ \text { SAP } & \text { Structural Adjustment Program } \\ \text { SDPRP } & \text { Sustainable Development and Poverty Reduction Program } \\ \text { TIN } & \text { Tax Identification Numbers } \\ \text { TPLF } & \text { Tigray People's Liberation Front } \\ \text { VAT } & \text { Value Added Tax } \\ \text { WB } & \text { World Bank } \\ \text { WPE } & \text { Workers Party of Ethiopia } \\ & \\ & \end{array}$




\section{Introduction}

There is a growing literature on taxation in Africa, including contributions from different disciplines such as economics and political science. An aspect that is sometimes overlooked, particularly in the former field of research, is the historical background that generated the tax systems that we can observe today. Although it is possible to trace common trends that extend across the African continent, individual countries have unique experiences with taxation. This is particularly true for Ethiopia, which in many ways is different to other African countries - not least because it was never colonised and has a history of statehood that makes it rather unique in the continent.

This paper reviews the fiscal history of Ethiopia focusing particularly on the period between 1960 and 2010, for which detailed fiscal data is available to underpin the analysis. While reviewing the key fiscal and economic events of this period, particular attention is paid to the relations between Ethiopia and its donors, which in fiscal terms can be seen as a relation between mobilising own tax revenue while negotiating aid and the conditions attached to it. The underlying question, explored in the broader historical context, is whether aid may discourage the government's efforts towards tax revenue mobilisation. By looking at the main drivers and constraints to tax revenue mobilisation in this period, the paper explores the role that aid and donors have played, and how this historical background influences Ethiopia today. While going through Ethiopian fiscal history, the elements that drive fiscal dynamics are underlined and explained in the specific political and cultural context of Ethiopia.

The bulk of the discussion provides a review of Ethiopian fiscal history that, to the best of my knowledge, is not available in such comprehensive terms for the period considered. This discussion is divided by regime: the Imperial period in section 3, the military regime in section 4 , and the federal period in section 5 . This part is based on secondary sources as well as on the documents and data collected during sixteen months of fieldwork between 2009 and 2012 . In addition, in-depth interviews were carried out during fieldwork, adding primary information to the historical account (see section 2 for more details on the methodology). The interviews particularly cover the most recent history of which more interviewees have direct experience. The historical review and the insights obtained during the interviews allow the identification of four inter-related underlying factors in Ethiopian history that influence the aid-tax relation, as well as fiscal policy more generally (section 6). The analysis suggests that a crowding-out effect between aid and tax in Ethiopia is particularly unlikely.

Against this background, the main contribution of this paper is to provide a comprehensive review of the fiscal history of Ethiopia that was not previously available. Although several documents report the key facts summarised here, they are relatively scattered, focus on different periods of time or topics, and are often difficult to access. This paper builds on this body of work by providing an Ethiopian fiscal history in a comprehensive yet concise way, including some original insights obtained through interviews and a review of unpublished documents. This review is particularly useful for two purposes in particular. First, and more generally, it can support researchers interested in analysing the Ethiopian economy by offering a simple and accessible historical account. This is particularly important for research that is primarily data- and desk-based, as it can help in developing theoretical and empirical models that are in line with the reality on the ground, as well as providing a basis for the validation and realistic interpretation of econometric results. Secondly, and more specifically, the paper provides an in-depth qualitative analysis of the aid-tax relation in Ethiopia, supported by historical facts and by insights obtained in the interviews. To illustrate the importance of taking history into account in case studies, this paper already underpins the econometric analysis and results in other published papers. ${ }^{1}$

\footnotetext{
${ }^{1}$ See Mascagni (2014), Mascagni and Timmis (2014), and Mascagni (2016).
} 


\section{Methodology}

This analysis is largely based on a period of fieldwork of sixteen months spent in Addis Ababa between 2009 and 2012. During this period I collected quantitative and qualitative data, including the macroeconomic data that constitutes my dataset, as well as a wealth of published and unpublished documents on the history and political economy of Ethiopia. The dataset covers the period 1960-2010, but this paper also briefly discusses events before and after these years when they provide relevant elements for understanding tax revenue mobilisation and aid in Ethiopia.

In addition to a thorough analysis of these documents and data, I also conducted a round of informal consultations and nineteen formal interviews. Interviewees belong to three broad categories: 1) government officials, 2) donor agencies and international organisations, and 3) independent experts. However, the boundary between these categories is often blurred as it is fairly common, for example, for government employees to join international organisations. Although all formal interviews are recorded, the details and the names of the interviewees cannot be disclosed. The institutions involved in the interview process included the Ministry of Finance and Economic Development (MOFED), the National Bank of Ethiopia (NBE), the World Bank, the International Monetary Fund, the European Commission and Department for International Development (DFID), as well as experts from Addis Ababa University, the Ethiopian Economics Association and the Ethiopian Development Research Institute. I made an attempt to interview the most senior available person in the relevant department of each organisation, as well as officials of lower seniority when they had specific expertise on the topic.

The semi-structured interviews were based on an interview guide that allowed flexibility in the order of the questions, while still ensuring that all relevant topics were covered with all interviewees. All questions were asked as open questions, avoiding any suggestion of possible answers. General questions were usually followed by related and more detailed follow-up enquiries. Assumptions and hypotheses were formulated as questions to assess their acceptability before proceeding further. Often interviewees were asked about specific results obtained in the preliminary data analysis and their possible interpretation. The interviews normally lasted for forty-five minutes, excluding the initial introductions and explanation of the process. The broad themes included in the interview guide are the following.

- Fiscal policy and reform, with a particular focus on taxation. This section includes questions on the sustainability of fiscal policy, revenue targets, tax composition, the objectives of tax policy and reform, and the constraints to tax revenue mobilisation.

- The characteristics of aid in Ethiopia and the relation with donors. This includes the following sub-themes: the type and quality of the relation with donors, conditionality and influence in policymaking, predictability and reliability, the determinants of variations in aid flows and aid modalities, including, in particular, grants and loans.

- The relation between domestic revenue mobilisation and aid. This section was mostly focused on the interviewee's perception of this relation and on the possible channels that would explain it, including: crowding-out, capacity-building, technical assistance, the effect of aid on the tax base, and trade liberalisation.

Although no systematic attempt was made to validate responses, two methods were used to partially cross-validate the results from the interviews and thus to make sure they correspond to reality. First, the same questions were typically asked to more than one person within the same institution, and across institutions. While differences in perception across institutions may be expected, within the same institution answers should be largely in line. This was indeed the case, and the broad themes emerging from the analysis were also shared across institutions. Secondly, after receiving an answer to one of the main questions, follow-up questions were asked to gain additional insight, and to test whether the answer had a solid and consistent basis. In 
addition, where possible, any information obtained in the interviews was cross-validated with available documents, reports and published material.

Interviews are at the core of the analysis, particularly for the last period of Ethiopian history (section 5). For earlier years (sections 3 and 4), the analysis is based mainly on an elaboration of secondary sources that are cited throughout. However original elements from interviews are also included in sections 3 and 4, and they were particularly useful in allowing a consistent reading of the history along the theme of this research.

\section{The Imperial period: 1941-1974}

While the imperial history of Ethiopia dates back several centuries, this section focuses on the period following the Italian invasion of 1935-41 to the 1974 revolution that led to the overthrow of Emperor Haile Selassie. When the Italians invaded Ethiopia in 1935, Haile Selassie, who had been in power for a few years, had to leave the country. Upon his return to Ethiopia in 1941, the empire was re-established, along with many of the institutions and laws that would shape fiscal policy for the next three decades. These reconstruction efforts, however, built on the pre-invasion period, when fiscal policy was already perceived as an important issue. The 1931 Constitution states that:

The receipts of the Government Treasury, of whatever nature they may be, shall be expended in conformity with the annual budget fixing the sums placed at the disposal of each Ministry.

This quote shows that the concept of budget as an instrument to connect revenues and expenditures was already present before the invasion, although it was formally implemented only in the early 1940s.

\subsection{Taxation in the agricultural sector}

During the Imperial period, the agricultural sector was particularly important, not only for its large contribution to the economy, but also because land was the basis of power. The traditional system of land tenure in Ethiopia is essentially based on the concepts of Gult and Rist. The former refers to the land that was given to landlords who had the task of administering it and who could extract tributes (gebbar) from tenants. The latter refers to the actual ownership of the land, that was given to peasants/tenants on the condition that they would fulfil their gebbar obligations. Under this arrangement rist ownership was considered permanent and it was inheritable, although in fact it was still conditional. Gebbar was usually paid by offering between one-third and one-half of the produce, labour services and gifts (Shiferaw Bekele, 1995; Brietzke, 1976). This system created a clear distinction between peasants and landlords, in addition to often being regarded as exploitative.

While this description of the land tenure system is highly simplified, it provides a basis for understanding the structure underlying the tax system. Upon the return of the emperor in 1941, the process of modernisation included the substitution of gebbar obligations with taxes payable in cash, introduced with the 1941 Land Tax Proclamation. ${ }^{2}$ Generally the modernisation process involved the gradual reduction of the administrative powers of landlords and it culminated with the abolition of gult in 1966. The process also involved the privatisation of land, or 'absolutisation' of rist.

In this context, the revised Land Tax Proclamation of 1944 further exacerbated the divide between landlords and peasants. By providing a tax exemption for the original landowner, the law essentially favoured absentee landlordism; this was rapidly becoming a problem as landlords

\footnotetext{
${ }^{2}$ The Land Tax Proclamation provided for tax payments to vary according to the type of land, particularly: fertile, semi-fertile and poor (Shwab, 1970).
} 
preferred to move to urban centres and engage in the growing manufacturing and construction sectors. An exemption was also provided for the Ethiopian (Coptic) Christian Church, which possessed a large amount of land. This provision not only meant foregoing substantial revenues, but also allowing the Church to extract its own tributes from its land.

In addition, an income tax was introduced in 1943 on personal incomes, rents and business profits, and providing for exemptions to foster investment. An attempt to introduce a tax on agricultural income was made in 1967 with the Agricultural Income Tax Proclamation. This proclamation was partly intended to address the demands for more equity stemming from the popular movements (see section 3.5). The final proclamation was only a watered-down and poorly-implemented version of the original intention, due to great opposition from landlords (Shwab, 1970; Brietzke, 1976). Popular protests also expressed opposition to the new law, such as the 1968 tax revolt in Gojjam. ${ }^{3}$ Notwithstanding these problems, Eshetu Chole (1984) holds that this tax still fared better than the land tax in terms of revenue generation. Indeed the share of direct taxes in total tax revenue increased from an average of 22 per cent in the five years before 1968 to 30 per cent in the five years after (see figure 1).

Figure 1: Composition of domestic revenue

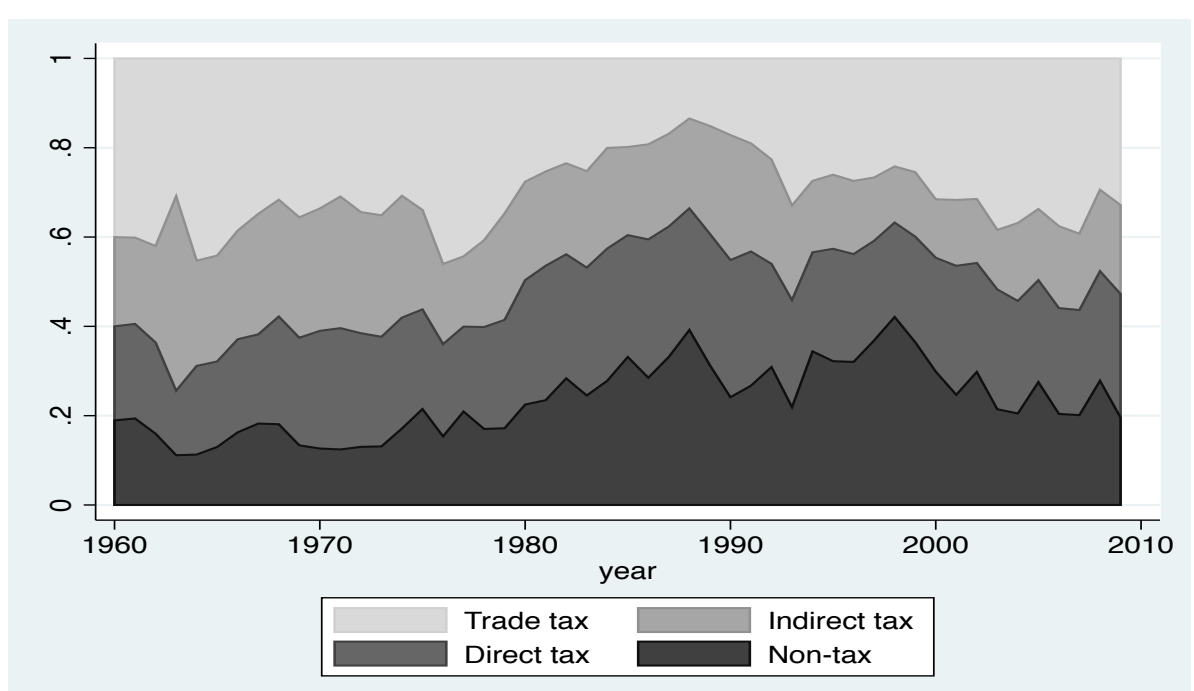

Note: Variables are calculated as a share of total revenue. Source: author's calculations using data from the Ministry of Finance and Economic Development

Generally, however, direct taxation in agriculture performed poorly both in terms of revenue generation and equity (Brietzke, 1976; Eshetu Chole, 1984). In addition Brietzke (1976) holds that the traditional tenures remained essentially unaffected by reform. This is certainly true in terms of the exploitation of peasants, particularly for extraction of resources. Landowners largely shifted the tax burden on to the farmers, who experienced a heavy tax burden for which they saw little in return. In addition, exemptions and fiscal incentives benefited the growing commercial agricultural sector, which was also largely reliant on exploitation of the peasants (Clapham, 1988). As a result, the Imperial Government became increasingly disconnected from the countryside, with little support and only weak links to the political interests there (Clapham, 1988; Shiferaw Bekele, 1995).

\footnotetext{
${ }^{3}$ The Gojjamis saw the law as a threat to the ancestral right of the people to the land (Clapham, 1988; Brietzke, 1976), and opposed land measurement provisions that would have implied a higher tax burden (Eshetu Chole, 1984; Shwab, 1970).
} 


\subsection{Other taxes: trade, consumption and the industrial sector}

Direct taxation was mainly levied in the traditional sector in rural areas, as the 'modern' industrial sector was still largely underdeveloped. The Italians never really had an industrial plan for Ethiopia, and therefore the decade after 1941 was mainly characterised by restoration and reconstruction in this sector. The Imperial government quickly recognised the importance of foreign investment for industrial development, and in 1950 issued the 'Notice for the encouragement of foreign capital investment' (Shiferaw Bekele, 1995). In this context, a number of fiscal incentives were set for foreign investors, particularly exemptions from business income tax, duty-free imports, and guarantees regarding the possibility of remitting a proportion of profits. In the following decade Ethiopia experienced accelerated industrialisation and a doubling of manufacturing production. This was due not only to fiscal incentives and the government's direct involvement (see development plans in section 3.3), but also to the federation with Eritrea in 1952 where industrialisation was much more advanced (Shiferaw Bekele, 1995).

Notwithstanding relatively high growth rates, the manufacturing sector in 1964/65 only contributed 3.1 per cent of GDP (see figure 2), and it was mainly in foreign hands. Moreover it was only bringing little benefit in terms of employment. The failure to boost manufacturing has also been linked to the traditional land tenure system, which was preventing the creation of domestic savings necessary to finance investment (Shiferaw Bekele, 1995). All this meant that the manufacturing sector was not contributing much to revenue.

Figure 2: GDP composition: selected sectors as a share of total

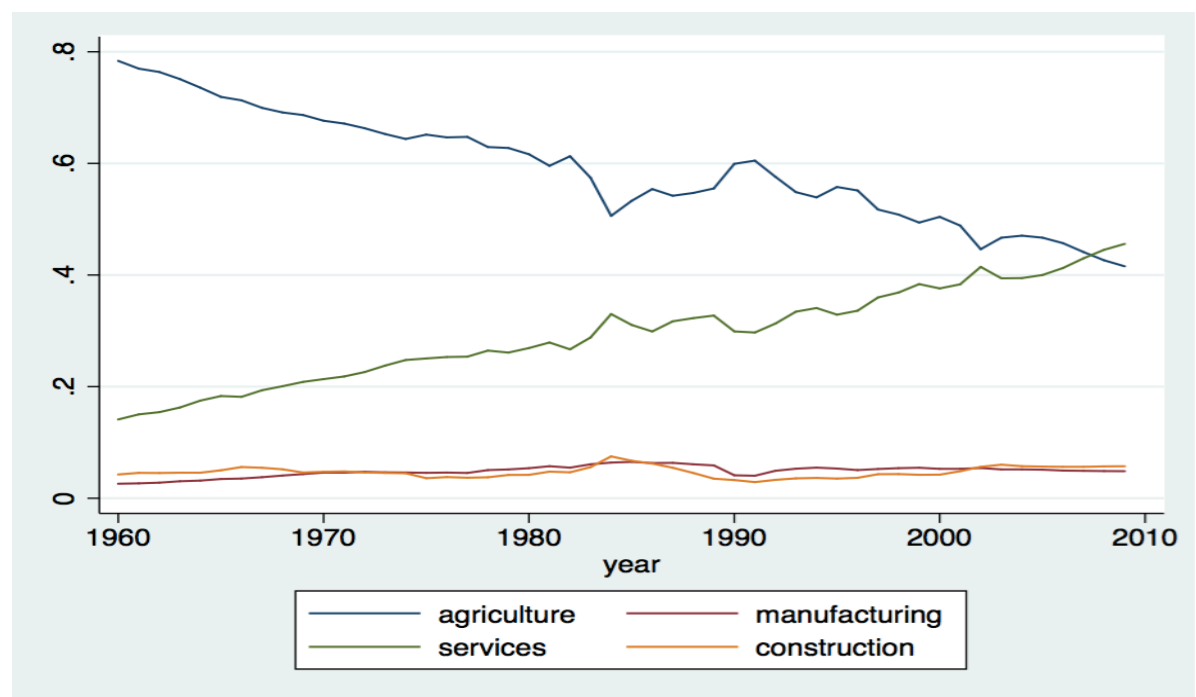

Source: author's calculations using data from the Ministry of Finance and Economic Development

As a result of the low tax revenue obtained though direct taxation, the imperial regime relied more on trade and indirect taxes. The high reliance on trade taxes appears clearly in figure 1, which plots the share of revenue types of total revenue. This is also confirmed by a higher share of this type of tax on total revenue under the emperor than during other regimes (see table 1).

Trade taxation was based on the 1943 Customs and Export Duties Proclamation. Import duties were the most important source of revenue, contributing 78 per cent of trade taxes on average between 1949 and 1974. This is consistent with the main industrial strategy of the time, based on import substitution, and naturally reflected high tariffs on imports (Shiferaw Bekele, 1995). However the revenue-generating potential of import duties was not fully exploited because of the increase in exemptions aimed at promoting industrial development (Eshetu Chole, 1984). Export taxes were levied mainly on coffee, and this introduced an element of instability due to volatility of prices in the international coffee market. 
Table 1: Selected indicators averaged by political era

\begin{tabular}{|c|c|c|c|c|}
\hline Indicator & Description & Imperial & Derg & EPRDF \\
\hline GDP per capita (ETB) & & 1001.2 & 995.8 & 1141.9 \\
\hline GDP growth & $\begin{array}{l}\text { growth rate of GDP at } \\
\text { constant prices }\end{array}$ & 3.4 & 1.7 & 6.5 \\
\hline Agriculture & sector's share of GDP & 71.3 & 59.3 & 49.9 \\
\hline Manufacturing & sector's share of GDP & 3.7 & 5.5 & 5.1 \\
\hline Trade openness & (import+export)/GDP & 10.5 & 13.4 & 29.4 \\
\hline Fiscal pressure on trade & $\begin{array}{l}\text { Trade } \\
\text { taxes/(export+import) }\end{array}$ & 21.5 & 23.1 & 14.8 \\
\hline Tax share & share of GDP & 5.3 & 9.2 & 9.6 \\
\hline Tax growth & tax revenue growth rate & 11.5 & 8.7 & 18.5 \\
\hline Grants & share of GDP & 1.0 & 1.8 & 3.0 \\
\hline Loans & share of GDP & 0.7 & 1.9 & 2.9 \\
\hline Aid dependency & $\begin{array}{l}\text { (loans }+ \text { grants }) / \text { total } \\
\text { expenditure }\end{array}$ & 21.1 & 19.7 & 28.2 \\
\hline Non-tax revenue & share of GDP & 0.9 & 3.3 & 3.8 \\
\hline Deficit & share of GDP & 0 & -2.1 & -1.4 \\
\hline Direct tax & $\begin{array}{l}\text { share of total tax rev- } \\
\text { enue }\end{array}$ & 25.9 & 36 & 34.5 \\
\hline Indirect tax & $\begin{array}{l}\text { share of total tax rev- } \\
\text { enue }\end{array}$ & 30.7 & 29.1 & 23.6 \\
\hline Trade taxes & $\begin{array}{l}\text { share of total tax rev- } \\
\text { enue }\end{array}$ & 43.4 & 34.9 & 41.9 \\
\hline
\end{tabular}

Note: Author's calculations using data from MOFED. Constant GDP was used at the denominator of sector shares, trade openness, to calculate GDP growth and GDP per capita. Current GDP was used to calculate shared of tax, loans, grants and deficit.

Domestic indirect taxation aimed to generate revenue and protect the domestic economy by granting lower rates for domestic products. Revenue was generated with taxes on alcohol, salt, fuel, tobacco and other excises on mass consumption goods, such as sugar and textiles, with large revenue-generating capacity (Shwab, 1970; Eshetu Chole, 1984). The most important source of indirect tax revenue, however, was transaction taxes, introduced in 1951 and combined with a turnover tax and a tax on construction works in 1963 (Shwab, 1970; Eshetu Chole, 1984). Finally, a stamp duty was introduced in 1957, but it did not generate much revenue.

\subsection{Increasing revenue needs and development planning}

The modernisation of the fiscal system was a priority for the emperor, as proved by the number of laws and reforms implemented in the early 1940s. Eshetu Chole (1984) holds that the system in place in the 1970s was essentially the same as that in place four years after the return of the emperor, although there had been changes and innovations in the meantime. The effort in tax revenue mobilisation, though with many difficulties, was sustained during the Imperial period, and was mainly driven by two elements: the expansion of the state and increased development expenditure. The first element entailed a great increase in the military and in the civilian bureaucracy, which were both receiving salaries in cash, besides other benefits (Shiferaw Bekele, 1995). A strong professional army was particularly needed in the context of tensions with insurgents in the newly-annexed Eritrea (federation took place in 1952), and a border dispute with Somalia that escalated to an armed conflict in 1964. 
The second element pushing the increase of revenues was increased development expenditure, which in turn helps to explain the need for an expanded bureaucracy. Development planning became a central issue in the international debate in the 1950s; Ethiopia, as a founding member of the UN, was well part of it. The country started working on sectoral programmes in 1945, with the ten-year industrial development programme developed with the support of the US Development Assistance Mission (Shiferaw Bekele, 1995).

These programmes paved the way for the three five-year development plans prepared under the Imperial regime, for the periods 1958-62, 1963-67 and 1968-1973. ${ }^{4}$ The planning process and implementation improved over the years, also thanks to the high involvement of foreign advisors throughout all the plans (Shiferaw Bekele, 1995). Foreign resources were largely used to finance all three plans, and Shiferaw Bekele (1995) reports that one-third of the first one was financed by foreign resources. However these figures are not directly comparable with the grants data used here, because it is not clear what proportion of the plans' financing was going through the Treasury.

The plans were a great step forward in setting clear goals and economic objectives. However their implementation faced several difficulties, with some observers arguing that the government's commitment to development was purely cosmetic, giving only an appearance of progress (Levine, 1961). Notwithstanding these difficulties and doubts, some effort was made to give a clearer direction in development. This included at least awareness on the importance of domestic revenue mobilisation, as shown by the following quotes from the Third Five-Year Development Plan (1968-1973) .

The plan calls for a growth of total tax revenue by almost $15 \%$ per year on average, or about 1.4 times faster than the growth of monetary production and income.

A central concern of the plan is the effective mobilisation of adequate financial resources. [...] This means in particular an emphasis on general Government and public sector finances to increase effectively the volume of public savings available to provide investment finance.

Finally, an element emerging clearly from the development planning process was the need to improve the quality and quantity of data available in the country. The scaled-up efforts in data collection led to the establishment of the Central Statistical Office (CSO) in 1961. From the very beginning the CSO engaged in more precise estimates of the national accounts, as well as on several national surveys to collect demographic and other socio-economic data. The first census survey took place in 1961 in Ethiopian urban centres (Shiferaw Bekele, 1995).

\subsection{Borrowing and external assistance}

The great increase in expenditure needs also raised more interest in borrowing and external assistance as sources of revenue.

Figure 3 shows that the government started making more systematic use of domestic borrowing to finance its budget, as deficits are registered in each year after the mid-1960s (Shiferaw Bekele, 1995). However deficits were still much smaller in magnitude than in later regimes (see average deficit figures by regime in table 1). By the early 1960s Ethiopia was also rather independent in terms of economic policy in general, having adopted its own currency in the mid-1950s and officially established its central bank (National Bank of Ethiopia) in 1963.

As far as external relations are concerned, there is little doubt that Ethiopia stands as a special case in Africa due to its independence from colonial powers. While this ensured a high degree of autonomy, it also meant that Ethiopia in the post-colonial period did not have a

\footnotetext{
${ }^{4}$ The fourth development plan, starting from 1974, was never implemented due to the end of the Imperial regime.
} 
Figure 3: Budget deficit as a share of GDP

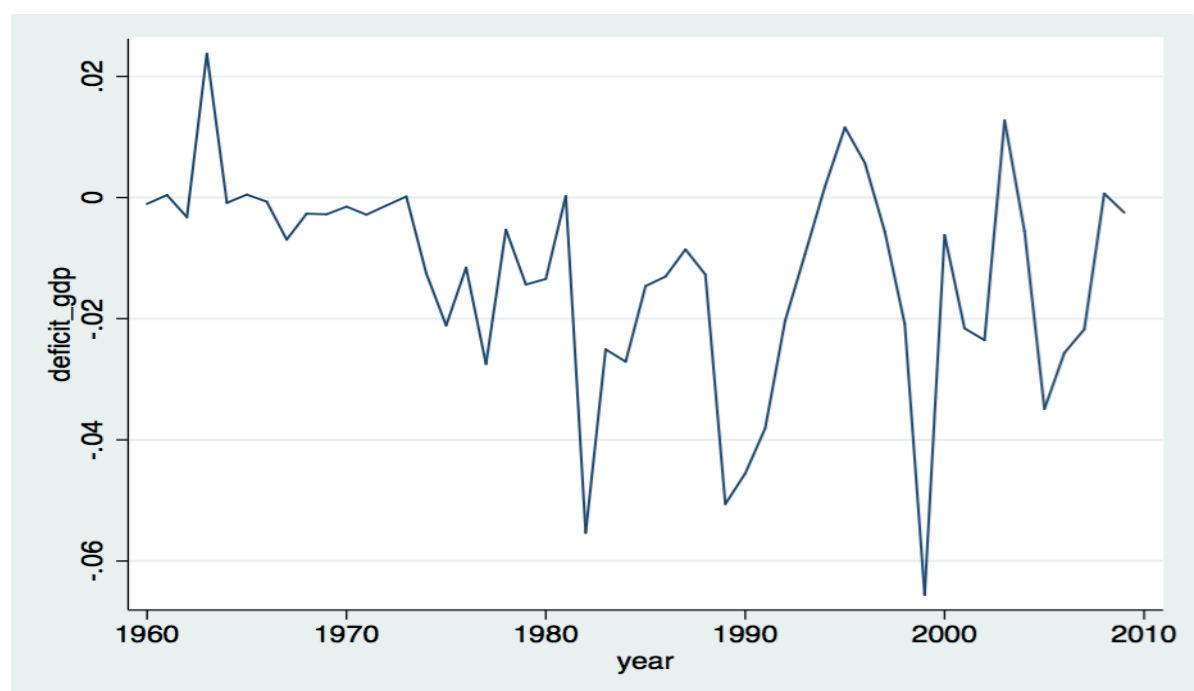

Note: Deficit is calculated as total revenue, including budget aid, minus total expenditure. Source: author's calculations using data from the Ministry of Finance and Economic Development

'patron' who would provide aid and lobby for it in the international arena. However Haile Selassie benefited from a high international standing and had strong external relations. Amongst others, Ethiopia was a member of the League of Nations from 1923, to which the Emperor appealed personally upon the Italian invasion of 1936; it was one of the founding members of the United Nations; and the Emperor had close ties with the USA that are well documented in Vestal (2011).

Immediately after liberation, the most influential country in Ethiopia was certainly Britain. The 1942 Anglo-Ethiopian Agreement provided for both financial assistance and great policy influence, to the extent that some observers likened the country to a British protectorate (Shiferaw Bekele, 1995). This situation was not well received by the Emperor and the agreement was ended in 1944, one year before its expiry, and replaced by a new one where the economic content was much more limited (Shiferaw Bekele, 1995).

The 1942 agreement provided for budget support in the form of grants that were limited in amount (Eshetu Chole, 1984), and soon overshadowed by increased American assistance (Shiferaw Bekele, 1995). Americans established a peer-to-peer relationship with Ethiopia ${ }^{5}$ and they actively supported independence from Britain. Americans also provided technical assistance on tax administration and policy, amongst other areas (Bahru Zewde, 2008). In return, the US obtained an ally in the Horn and the Kagnew military telecommunications station, a base of great strategic importance in Eritrea - this was only closed in 1977 when the Americans fully withdrew from Ethiopia.

Besides the US, Ethiopia could count on bilateral assistance from the Federal Republic of Germany, the Soviet Union, Czechoslovakia and Yugoslavia. Multilateral organisations such as the World Bank (WB), the World Food Programme and other UN agencies were also active in the county. UN experts in the 1960s, and a WB team in 1973, visited the country specifically to give recommendations on the tax system. These focused on the need to improve progressivity and to reform land taxation, and the WB team in particular underlined the issue of exemptions, de jure or de facto, for commercial agriculture and landlords (Eshetu Chole, 1984).

Generally, however, external aid remained consistently lower than the Ethiopian requests, although foreign grants and loans together contributed one-fifth of total expenditure on average

\footnotetext{
${ }^{5}$ This relation was formalised in 1943 with the Mutual Aid Agreement, and later confirmed with the Treaty of Amity and Economic Relations of 1951.
} 
during the Imperial period (see table 1).

\subsection{Opposition movements and the decline of the regime}

A central characteristic of the Imperial style of government, which remained a trait of Ethiopian political culture more generally, is related to distrust, secretiveness and suspicion (Levine, 1961; Clapham, 1988; Medhane Tadesse and Young, 2003). Levine (1961) describes this system of mutual spying and constant shuffling of political appointments, which was aimed at minimising organised dissent and ensuring loyalty to the emperor. This climate greatly frustrated the growing educated elite, which found itself in a purely passive and subordinate role.

The emperor was indeed troubled by the idea that someone could get enough power to challenge him (Levine, 1961). This fear materialised in a failed military coup d'état in 1960: this aimed to establish a more democratic and progressive government, and to start economic and political reforms to truly modernise the country. Even if the coup eventually failed, it had great political impact. The emperor accelerated the reform process, particularly with the Tax Proclamation of 1961, the Investment Decree of 1963, the Investment Proclamation of 1966, the Agricultural Income Tax Proclamation of 1967, as well as the establishment of the Confederation of Ethiopian Labor Unions (CELU) in 1962.

Notwithstanding these reforms, the underlying tensions were far from resolved. First of all, the implementation of the new laws was only half-hearted, and the privileges of landlords were largely maintained, including fiscal ones. Tax rebellions in Bale in 1964 and, most notably, in Gojjam in 1968 are examples of the growing discontent (Chege, 1979; Brietzke, 1976; Mengisteab, 1990). The land tenure system was not only considered exploitative, with a great fiscal burden on the peasantry and growing class inequality (Gilkes, 1975), but also seen as an obstacle to agricultural development.

These tensions were further fuelled by economic decline in the 1960s and 1970s due to the closure of the Suez canal in 1967 and the 1973 oil crisis; these contributed to the loss of competitiveness of Ethiopia as well as increasing prices. Gilkes (1975) estimates that in 1973 prices rose by 20 per cent and that, in the first quarter of 1974 alone, the price rise was equivalent to an annual rate of 80 per cent. Finally the famine in 1973 exposed the inadequacy, or the unwillingness, of the government to reach to rural areas and provide the basic services and food that were desperately needed in the affected areas (Clapham, 1988).

The fall of the emperor was eventually the result of a series of mutinies, strikes and demonstrations, which characterised the last year of the Imperial regime. The masses demanded the sacking of corrupt officials, democracy, pay increments, administrative reforms, the right of association and better working conditions. Last, but not least, the agrarian question was at the centre of the debate, with the slogan 'Land to the Tiller' (Economic and Political Weekly, 1978; Chege, 1979; Gilkes, 1975). However the revolution was largely an urban process, and the peasantry was not very engaged with it (Chege, 1979; Clapham, 1988). Protests culminated in the month-long general strike called by CELU in March 1974, and did not stop until the Emperor was deposed on 12 September 1974. By this time the Derg, ${ }^{6}$ the military junta that would rule Ethiopia until 1991, was largely present in the upper ranks of government (Gilkes, 1975; Economic and Political Weekly, 1978).

Details on the revolution that characterised the transition between the Imperial period and the Derg, as well as the main actors involved, are described in section 4.1.

\footnotetext{
${ }^{6}$ At this time the military junta was not yet known as Derg but as the Military Coordinating Committee (MCC). The MCC was established in June 1974 and it became the Provisional Military Government (PMG) after the coup in September 1974. The PMG was the predecessor of the Derg.
} 


\section{The Derg: $1974-1991$}

The Derg regime took power in 1974, and it was led for most of the period by Mengistu Haile Mariam. It has been divided by some observers (Clapham, 1989; Keller, 1985) into three periods, as follows. The mobilisation period (1974-78) started with the toppling of the old regime, and was characterised by the struggle for power of the different actors involved in the revolution. The regime was at this time mainly concerned with its survival. The campaign period (1978-1984) saw the emergence of the main traits of the regime, such as centralisation and collectivisation, although state institutions were still at an embryonic state. The plan period (1984-1991) was characterised by the establishment of socialist institutions, as well as the scaling-up of planning efforts. While this periodisation is not strictly followed in this section, the events discussed can easily be traced back to it.

\subsection{The revolution and its opponents}

The 1974 revolution that overthrew the emperor had two main driving forces: the urban class, represented by CELU and the Ethiopian People's Revolutionary Party (EPRP), and the armed forces. During the revolution the two forces shared a common target: the autocracy and the feudal system. However in 1974 the EPRP was still young and lacked the organisation and leadership necessary to be the vanguard of the movement (Chege, 1979; Economic and Political Weekly, 1978). The armed forces took advantage of this vacuum of power and established themselves as the leading force of the revolution.

In 1974 the new military government took power in Ethiopia, and declared itself anticapitalist, anti-imperialist and anti-Marxist, under a rather general slogan 'Ethiopia Tikdem', or 'Ethiopia first'. Despite its role in leading the revolution, it was clear from the beginning that the Derg lacked a social base and legitimisation amongst ethnic groups (Economic and Political Weekly, 1978; Chege, 1979; Gilkes, 1975). Indeed the divergence in ideals between the two forces of the revolution quickly became painfully clear in its aftermath.

Both CELU and EPRP, along with students, opposed the military regime from the beginning with massive demonstrations organised across the country. This dissent was met by repression from the regime in what is known as 'Red Terror', which caused massive bloodshed between 1975 and 1978. Both CELU and EPRP were neutralised through assassinations and detention. The former was eventually replaced with the All-Ethiopia Trade Union, which became essentially just another repressive arm of the regime.

The students also paid a high price for their resistance, facing armed repression and group executions throughout the spring of 1977 (Markakis and Ayele, 1977). An educational programme called zemecha was carried out, with the official aim to improve literacy and health in the context of the land reform; it effectively displaced students to rural areas. However some observers note that a possible hidden goal was to avoid assembly and demonstrations at universities (Gilkes, 1975; Brietzke, 1976).

In addition the Derg was opposed by ethnic minorities who, after centuries of Amhara domination, were becoming increasingly sensitive. While at the beginning the military regime did not have a clear ethnic connotation, it was perceived to be Amhara-dominated and this perception proved true in later years (Chege, 1979; Clapham, 1988; Gilkes, 1982). The slogan 'Ethiopia First' and the nationalist ideology of the Derg were not well accepted at the regional level in a country that never really had a national identity (Keller, 1981; Clapham, 1988).

The main threats were from the Eritrean People's Liberation Front (EPLF), which by 1977 had control over most Eritrean towns, and the Somali groups in the Ogaden region. Moreover the Tigray People's Liberation Front (TPLF) was created during the revolution; it became increasingly organised during the Derg regime, eventually leading its defeat sixteen years later. Ethnic revolts were, again, met with military repression and with only few concessions that largely remained dead-letter (Clapham, 1989). 
Finally, the Derg was not immune from internal conflict. Internal divisions concerned the response to the Eritrean revolt, the fate of the Emperor, the nature of government, and the violent repression of any opposition to the military government (Economic and Political Weekly, 1978; Chege, 1979; Gilkes, 1975, 1982). Many prominent figures of the Derg were executed, and in 1977 Mengistu Haile Mariam eventually emerged as the undisputed leader.

By 1978 most movements of dissent dissolved, having being frightened by the experience of the Red Terror. However the repression did not settle the movements in the countryside, which continued throughout the period (Clapham, 1988).

\section{Land reform and agricultural sector}

To address the problem of the lack of a social base, the Derg acted on two fronts. First, it made demagogic claims of carrying out a socialist revolution, aware of the appeal this would have to the masses. Second, it carried out a comprehensive land reform and a programme of nationalisation. At the beginning of 1975 all banks, insurance companies, industrial and commercial firms were nationalised. The Land Reform Proclamation of March 1975 made all land the collective property of the Ethiopian people, and it redistributed it to the peasants. Hired labour in agriculture and the sale of land plots were prohibited (Ottaway, 1977; Mengisteab, 1990; Cohen et al., 1976). All large commercial farms were nationalised and became state farms, collective farms, or were distributed to the peasantry (Brietzke, 1976; Cohen et al., 1976).

These policies had a highly symbolic value against the background of feudalism. By annulling all previous obligations to landlords, the reform deprived the ruling class of the basis of their power (Brietzke, 1976). The land reform thus paved the way for the consolidation of the Derg's power by increasing its legitimacy amongst peasants and by weakening the opposition (Cohen et al., 1976; Brietzke, 1976). While obligations to landlords were annulled, taxes to the government were still due. Initially the 1967 Agricultural Income Tax Proclamation remained in effect, since that did not depend upon ownership (Brietzke, 1976); it was later replaced by

the Rural Land Fee and Agricultural Activities Income Tax Proclamation in 1976.

The new legislation also provided for the creation of peasants associations (PAs) and urban dwellers associations (kebele) throughout the country. Their main role was to implement the land reform and to coordinate the redistribution of land (Ottaway, 1977). More generally they were local administrative units, also in charge of collecting taxes (Ottaway, 1977; Mengisteab, 1990; Cohen et al., 1976; Brietzke, 1976). However capacity was low at the local level and the government committed to reducing illiteracy through the zemecha and other campaigns. The campaigns had some success, with illiteracy being reduced from 90 per cent in 1973 to 65 per cent in 1981 (Griffin, 1992).

As the reform was being implemented, three main forms of agricultural production emerged: family farms, cooperatives and state farms. Peasant or family farms remained the most widespread mode of production, occupying over 90 per cent of the cultivated area, and they were organised into peasants associations. Cooperatives started to be more forcefully promoted by the government after 1978, along with collectivisation, but the expected growth in this sub-sector never occurred, neither in terms of quantity nor productivity. Finally state farms stem from what were commercial farms before the nationalisation of 1975 (Griffin, 1992; Keller, 1985; Clapham, 1987). The agricultural development strategy of the government was largely focused on state farms and cooperatives, despite them being less productive than family farms (Mengisteab, 1990; Clapham, 1987). Consequently they were allocated the lion's share of public resources, including more favourable tax treatment than family farms (Ottaway, 1977; Mengisteab, 1990).

\section{Manufacturing sector}

The manufacturing sector was also involved in the nationalisation programme, as all large- 
scale industries were put under the control of the Ministry of Industry ${ }^{7}$ in 1976 (Wubneh, 1990; Griffin, 1992). Private initiative was generally discouraged, including legal restrictions for capital investments (Griffin, 1992). Since the nationalisation programme did not provide for any restrictions on compensation, foreign investment stopped flowing into the country. Any incentive to improve profitability was slashed by a top marginal tax rate of 89 per cent. In addition, all the after-tax profits of state firms were to be transferred to the government (see section 4.3).

Besides government policy, the private sector also suffered because of internal conflicts that led not only to the destruction of some factories in Eritrea and in the East, but also to shortages of raw materials and spare parts, difficulties in transport, the lack of foreign exchange and power shortages (Griffin, 1992).

However Eshetu Chole (2004) holds that the performance of the industrial sector was still more respectable than that of agriculture. This is confirmed by national accounts data that indeed shows an average growth rate in the agricultural sector of 1.5 per cent, as opposed to 3.8 per cent in the manufacturing over the Derg period. Despite this better performance, manufacturing remained only a marginal contributor to GDP under the Derg, as shown in figure 2 (although its share was larger than in the Imperial period (see table 1)).

As a result of bad economic policies, both in the agricultural and industrial sectors, GDP per capita was generally lower in the first years of the Derg than at the end of imperial rule (see figure 4).

Figure 4: GDP per capita at constant prices

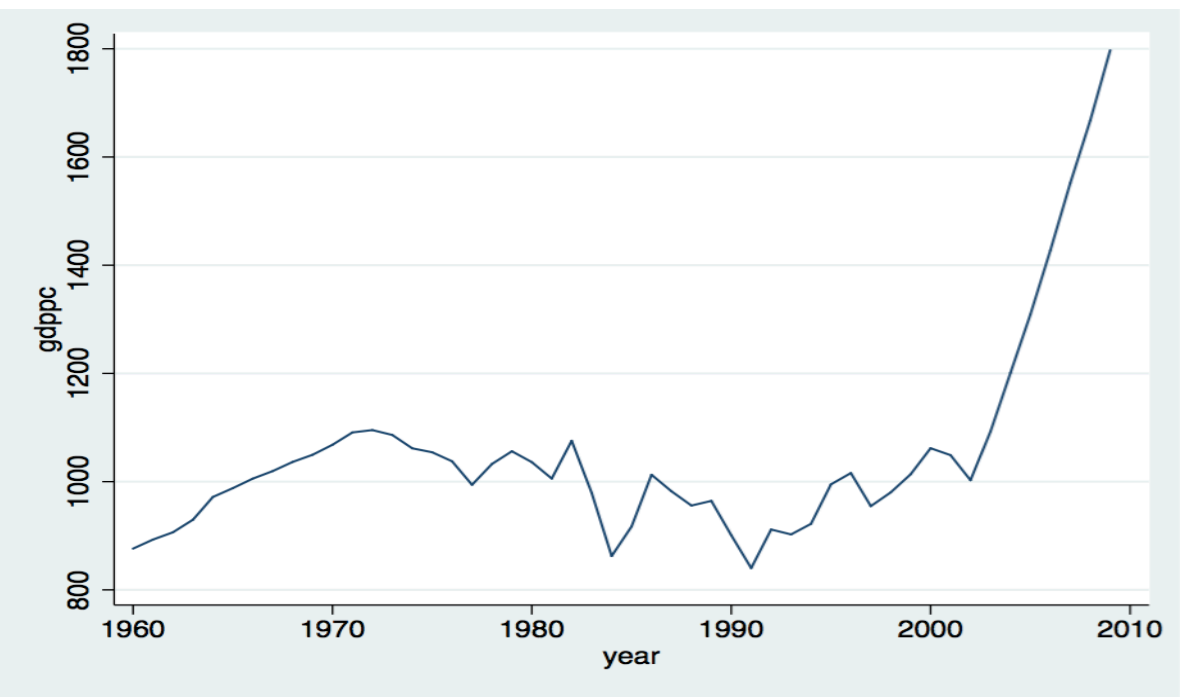

Source: author's calculations using data from the Ministry of Finance and Economic Development

\section{Consolidation and planning}

Starting in 1979, with the establishment of the Committee for Organizing the Party of the Workers of Ethiopia (COPWE), the Derg put a systematic effort into building the institutions of a socialist state (Keller, 1985). The whole process however was slow, directed from the top, and it fully reflected existing power structures (Keller, 1985, 1981; Gilkes, 1982).

In 1984 the Workers Party of Ethiopia (WPE) was launched; a new constitution was introduced in 1987, formally establishing the People's Democratic Republic of Ethiopia. Both the constitutional process and the formation of the party were attempts by the Derg to gain polit-

\footnotetext{
${ }^{7}$ The Ministry of Industry in turn was under the Office of the National Committee for Central Planning (ONCCP).
} 
ical legitimisation for the increasingly unpopular military ruling class. However no concessions were made on the demands of opposition groups, and thus the process could at best deliver an appearance of representation (Clapham, 1988).

On the planning side, the Office of the National Committee for Central Planning (ONCCP) was part of the new institutional set-up, and was intended to take the lead on economic development. A decade after the revolution, in 1984 it launched the Derg's first development plan: the Ten Year Development Plan. The timing of its launch was particularly unfortunate as a major famine broke out in 1984, necessitating a shift of all national efforts towards the emergency. The famine also accelerated the villagisation and resettlement campaigns that were essentially representing the core of development policy before the Ten Year Plan (Keller, 1985; Clapham, 1987). The weakness of the plan's design and implementation was exposed by a consistent shift of public expenditure away from development and services towards control functions. This is particularly the case of military expenditure that was needed to maintain the Derg's authority (Clapham, 1988; Eshetu Chole, 2004).

As the consolidation process continued and power concentrated increasingly in Mengistu's hands, continuity with the Imperial regime became more clear. The central thesis of Clapham (1988) is that:

There has been a revolution. Much has changed. But a sense of what has changed, and how, is to be gained only through an appreciation of continuity.

This continuity, in particular, entailed the political culture and style of administration, based on personal relations, suspicion, and the lack of independent institutions; nationalism expressed in the slogan 'Ethiopia First', that can be compared to Haile Selassie's vision of 'Greater Ethiopia' (Keller, 1985); and the cult of personality and centralism in decision-making that increasingly developed within the Derg. The strong state and the attitudes towards political authority developed under the Imperial regime were in fact not an obstacle, but rather an advantage to the new military government and a key to the success of the revolution (Clapham, 1988).

The Derg never finally obtained legitimacy and support from the people. An attempted coup in 1989, and military losses in Tigray and Eritrea, which by the late 1980s were fully in the rebels' hands (Young, 1997), clearly exposed the weaknesses of the Derg. It was the beginning of the end for the military regime.

\subsection{External relations and aid}

Foreign support to Ethiopia at the time of the 1974 revolution was largely American. However the US failed to protect the Imperial regime against the revolution. On the contrary, it kept cosy relations with the new government, notwithstanding its anti-imperialist and socialist proclamations, and it even struck a deal with the Derg to ensure the provision of arms, tanks and jet fighters. In the late 1970s, however, the relations with the US cooled because of concerns on human rights violations and the expropriation of American private assets without compensation (Economic and Political Weekly, 1978; Keller, 1985; Clapham, 1988). American aid was eventually withdrawn in 1979, although US humanitarian assistance kept flowing.

European countries instead remained largely present in Ethiopia, providing no evidence of discrimination due to the Derg's socialist policies (Clapham, 1988). Ethiopia was part of the Lomé Convention with the European Community after it came into effect in 1975, also benefiting in terms of aid (Clapham, 1988). Western countries remained Ethiopia's main trading partners (Clapham, 1987; Keller, 1985), while foreign investment decreased sharply.

The decrease in American foreign aid was largely compensated by an increase in Soviet aid and military assistance (Keller, 1985). The Soviet Union and Cuba provided arms, military training and economic support to the Derg, which was crucial in the fight against the opposition, and particularly against ethnic rebellions in Eritrea (1979) and the Ogaden (1978). The 
importance of Soviet military support pushed the Derg to proclaim its Marxist-Leninist inclination even more forcefully (Chege, 1979; Markakis and Ayele, 1977; Keller, 1981; Clapham, 1988). The interviews confirmed that the USSR was the most influential foreign actor during this period, while Western countries had little or no political leverage despite their presence in the country.

The USSR presence further encouraged the switch from developmental to military expenditure that the Derg was already pursuing. Moreover, it implied a decrease in the quantity and quality of external advice that Ethiopia was receiving, in turn resulting in poorer development strategies. Despite this situation, many of the interviewed observers agreed that the Derg still had some commitment to development, although it largely failed to achieve much mainly because of conflict and bad policies.

While it may be tempting to consider Ethiopia under the Derg as a rather passive actor in the hands of the USSR, this would be a very poor representation of reality. The Derg had its own view on Ethiopian development, which focused largely on nationalism, and it diverged from the Soviet idea of socialism. Indeed, in the consolidation phase, pro-Moscow Derg and WPE members were systematically neutralised in favour of nationalist views, (Keller, 1985). Moreover, relations with the USSR were rocky, although strong, as shown by the early ending of two state visits of Russian ambassadors because of tensions with the Ethiopian government (Clapham, 1988). Mengistu was very sensitive to Soviet foreign intervention in domestic affairs, perhaps because his alliance with Moscow was sometimes perceived as lessening his standing as a national leader (Clapham, 1988).

Towards the end of the Derg period, Ethiopia became largely isolated in the international scene. On the Soviet side, the fall of the Berlin Wall and the rise to power of Gorbachev resulted in a significant reduction of Soviet aid to Ethiopia. On the Western side, the increasingly evident weakness of the regime caused Western donors to be more cautious and to give more attention to the rebel movement in Tigray. However their understanding of the political dynamics in Northern Ethiopia ${ }^{8}$ remained very limited until 1991 (Young, 1997).

\subsection{Fiscal trends}

The 1974 revolution sparked demands from the masses both in the urban centres and in more remote ethnic communities. These political demands were readily directed to the military government itself as soon as it took power. Indeed Clapham (1988) holds that 'the major effect of revolution was $[\ldots]$ not that the state apparatus was weakened, but that it was required to do much more.' This increased role of the state implied a need to increase public resources, and it was largely in line with the socialist ideology embraced by the new regime.

Figure 5 shows clearly that, after its establishment in 1974, the Derg increased both tax revenue and expenditure. The former is particularly impressive considering that the new regime had neither full control of the country nor popular support in its early years. It is therefore plausible that the increase in revenue was more the result of coercion and intimidation than of a genuine social contract, particularly given the contemporaneous shrinking of the development and services budget in favour of military expenditure.

Non-tax revenues also increased significantly, initially due to the expropriations carried out in the first years of the regime, and to the contribution of state firms to the budget through 'government investment income'. This represented the transfer of post-tax profits to the government, so that state enterprises contributed both through tax and non-tax revenue. In addition the government was extracting surplus from the agricultural sector using a system of quotas and price controls, although these resources did not show in the budget.

Despite the increase in revenues, the government was still experiencing a resource gap resulting in increasing levels of debt (Eshetu Chole, 2004). The increase in budget deficit appears

\footnotetext{
${ }^{8}$ Mainly in Tigray and Eritrea, which at this time were still part of Ethiopia.
} 
Figure 5: Trends in fiscal variables

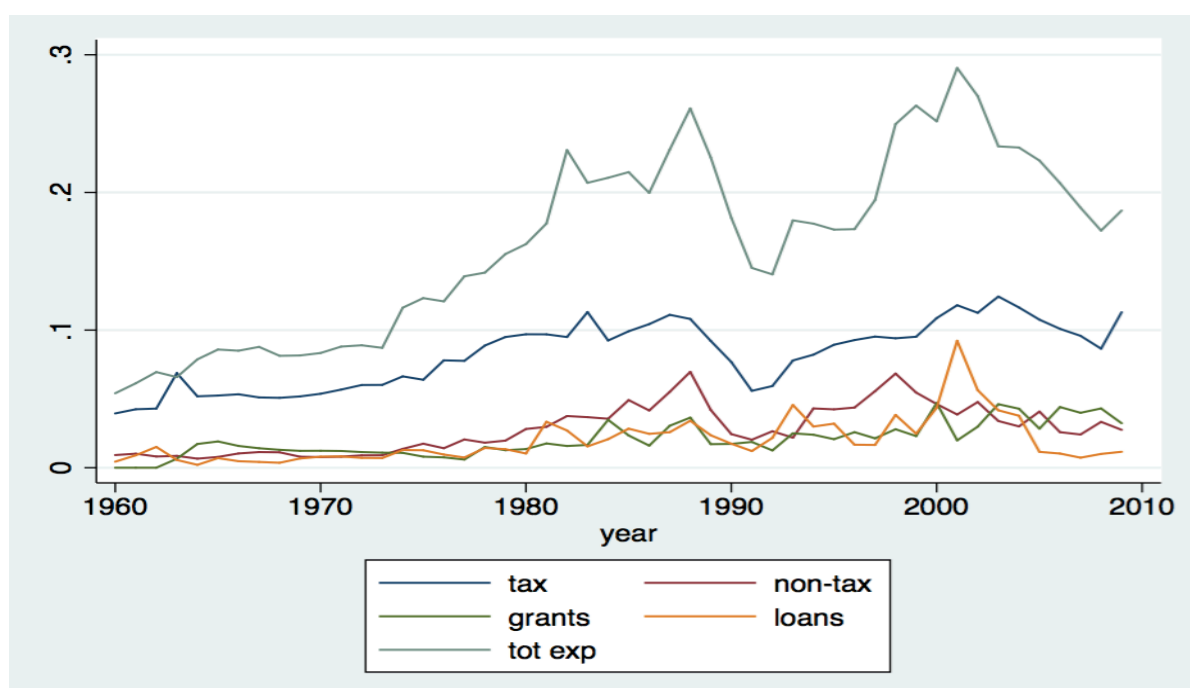

Note: all variables are expressed as a percentage of current GDP. Source: author's calculations using data from the Ministry of Finance and Economic Development

clearly in figure 3: this shows an increase in the use of this instrument starting from the 1974 revolution. The situation regarding foreign debt deteriorated so much that in 1990 payments of all debt obligations were frozen, apart from those to international financial institutions and some other critical ones (Eshetu Chole, 2004).

All fiscal variables, and particularly tax, non tax revenue and expenditure, seemed to peak in 1988/89 then decrease steadily until the end of the regime in 1991. This decline is due to the deteriorating economic, military and political situation in the country. The economic crisis is essentially the result of over a decade of poor economic policies, including the over-extension of the state in the economy, a bad investment climate, and the deterioration of terms of trade (Eshetu Chole, 2004). Militarily, the Derg was suffering huge losses and defeats in the north, and the morale of the armed forces quickly deteriorated. This situation was further worsened by the attempted coup, which not only was a demonstration of political dissent, but also showed a fracture within the military.

The economic crisis was accompanied by a fiscal collapse. On the domestic side, this was fuelled by the loss of control of rebel areas as well as the declining GDP per capita (see figure 4). Moreover, the initial returns from increased extraction capacity were vanishing (Clapham, 1988). While high tax rates might have generated revenues in the beginning, they, together with other Derg policies, contributed to a shrinking of the tax base that kicked in only later and resulted in a decrease in tax revenue. A government official of the time noted that top tax rates were applied to a decreasing amount of people and businesses, as the country was becoming impoverished. On the international side, it was due to the disruption of aid flows both from the Soviet bloc and from Western donors, who thought the days of the Derg were numbered and adopted a 'wait and see' attitude (Eshetu Chole, 2004).

\section{Taxation}

As far as taxation is concerned, the distinctive feature of the Derg regime was the exceptionally high marginal tax rates imposed on income, in all sectors. The agricultural income tax had an 89 per cent rate for top brackets - for incomes above 36,000 ETB per year (Griffin, 1992). Comparable rates were also applied to personal incomes and business profits.

Clearly this situation fuelled economic decline and increased tax avoidance. As emerged from interviews, nobody had any incentive to increase their income, individuals and private 
businesses alike, given that the benefit would accrue mainly to a state that was delivering little in return. There is no doubt that this attitude contributed to the economic decline that became apparent in the last years of the regime.

However the Derg could count on relatively easy-to-collect taxes such as indirect and trade taxes. These were relatively easy to administer, as they were collected at the factory gate and at the border, respectively. Moreover the large state sector, including farms and enterprises, was a source of both tax and non-tax revenue. Finally, most taxes were collected in urban centres that largely remained under government control, even when the guerrilla war was ongoing in the countryside (Young, 1997; Clapham, 1988).

As far as agricultural taxation is concerned, two main tax types were levied: the agricultural income tax and the land use tax. These were introduced by the Derg, and they largely replaced the previous system of obligations. The contribution of agricultural taxation to state revenue more than doubled in the early years of the Derg (Markakis, 1989). However, tax incidence in rural areas after the reform is estimated at 5 per cent (Griffin, 1992), and Eshetu Chole (2004) holds that generally the agricultural sector was not an important source of tax revenue. Although peasants were requested to pay tax, they received little in return as most resources were directed to state farms (Markakis, 1989).

Family farms were also discriminated against in terms of the land use tax, which was levied irrespective of location or soil fertility. The annual rate was 10 Birr for those who were not members of cooperatives, 5 Birr for those who were members, and 2 Birr per hectare for state farms (Eshetu Chole, 2004). The tax was levied per holding and regardless of the plot size. Also falling on the agricultural sector were trade taxes, with the coffee sector being one of the main sources of revenue. Clapham (1987) reports that the share of export price paid to producers fell from 67 per cent before the revolution to 33 per cent afterwards. Notwithstanding this heavy burden on producers, little evasion was possible given the tight controls of the government, which included internal customs to prevent smuggling (Clapham, 1987).

In a last attempt to gain popularity, and realising the declining international standing of socialism, the Derg tried to introduce some degree of liberalisation in the economy starting from 1988. In particular this entailed the expansion of fiscal incentives for investment, including exemptions from custom duties and income tax. Moreover in 1990 the top marginal income tax rate was reduced from 89 per cent to 59 per cent (Eshetu Chole, 2004). However the reform of the dying regime was too little and too late.

\section{The Ethiopian People's Revolutionary Democratic Front: 1991- 2010}

Throughout the Derg regime, liberation movements were active in the country. The Tigray People's Liberation Front (TPLF) and Eritrean People's Liberation Front (EPLF) were the main two forces that eventually led to the defeat of the military regime. After sixteen years of armed struggle, starting in 1975, they finally reached Addis Ababa in May 1991. Recognising the defeat, which to many observers had been just a matter of time for a couple of years, Mengistu fled to Zimbabwe. Proving its weakness, the façade of political institutions the Derg had created, including the Worker's Party of Ethiopia, vanished instantly upon the fall of the regime (Markakis, 2011).

\subsection{Transition and ethnic federalism: 1991-1998}

The TPLF both played a central role in defeating the Derg, and also shaped Ethiopian politics after 1991. During the armed struggle it developed strong local ties through its fighters, who were living in very modest conditions with the peasantry. The TPLF could also count on a very strong organisational, administrative and military apparatus, used to administer the liberated 
territories under the Derg and to keep the military regime confined to urban areas. In 198082, the TPLF controlled about 80 per cent of the territory in Tigray where 90 per cent of the people lived (Young, 1997). The military progress however was compromised by the famine of 1984, which completely disrupted the TPLF's activity. The organisational skills developed in the 1980s proved crucial when the front had to govern the whole country. Finally, the TPLF had a well developed ideology based on revolutionary change, democracy, transparency, collective leadership and the refusal of a cult of personality for a single leader.

Aware of the need to give itself a national standing in view of the weakening and eventual defeat of the Derg, the TPLF promoted the creation of the Ethiopian People's Revolutionary Democratic Front (EPRDF) in 1989. The EPRDF, which is still governing Ethiopia today, is an umbrella organisation composed of different ethnic-based fronts and parties, including the Amhara, Oromo, Tigrayan and Southern people. The EPRDF initially embraced a Marxist ideology, which was later softened to ensure alliances in the West (Young, 1997; Hagmann and Abbink, 2011).

While the experience of the struggle was crucial to TPLF and EPRDF success, it also posed some difficulties as regards the transition from a guerrilla movement to a national government. First of all, there was a need for national representativeness beyond the northern provinces. Second, some of the traditional practices of the EPRDF, such as the system of evaluation of the leadership, ${ }^{9}$ found opposition amongst bureaucrats at the national level. Third, the rise to power of EPRDF resulted in a gradual distancing of its leadership from its peasant base, which was ever more anxious to see its demands met as well as improvements on poverty and development (Young, 1997; Medhane Tadesse and Young, 2003).

After the transitional conference that eventually formalised the EPRDF government with Meles Zenawi as president, the focus was largely on ethnic groups and nationalities. The EPRDF essentially accepted the right of self-determination 'up to and including secession', which was enshrined in the 1994 Constitution. On this basis, Eritrea separated from Ethiopia in 1994 following a referendum that resulted in a staggering 99.8 per cent of the votes in favour of independence (Young, 1997). In 1992 regional elections were held, where ethnic groups were allowed to choose leaders from their own background (Young, 1997; Abbink, 2011). Elected officials were trained in EPRDF special schools on the party's programme and then sent back to the regional level (Markakis, 2011). In the meantime EPRDF troops and officials were sent to the periphery to ensure control and administrative support. The only challenge for the new government was the Oromo Liberation Front (OLF), which never collaborated with the EPRDF and boycotted the 1992 elections. General elections were held in 1995, resulting in an overwhelming EPRDF victory, the establishment of the Federal Democratic Republic of Ethiopia, and the confirmation of Meles Zenawi as leader (now prime minister).

As in the case of the Derg, the EPRDF benefited from the legacy of a strong state, which was used as an administrative base rather than being dismantled. Indeed kebeles ${ }^{10}$ were maintained, and they later became a central tool for government administration and control in the periphery. The challenge therefore was the democratisation and legitimisation of a state that was largely inherited by the Derg (Young, 1997).

\section{Ethnic federalism}

The most important characteristic of the new government by far was the decentralisation of the state and introduction of ethnic federalism. The level of ambition and radical change of the federalist project cannot be underestimated, as underlined by two interviewees with a long experience in Ethiopia. This is enshrined in a quote from Meles, from an interview released in

\footnotetext{
${ }^{9}$ The evaluation system adopted during the armed struggle was called gim gimma, and it was essentially a process of popular critical evaluation aimed at assessing the front's policies, programme, leadership and conduct (Medhane Tadesse and Young, 2003; Hagmann and Abbink, 2011).

${ }^{10}$ Kebeles are the lowest level of decentralised public administration.
} 
2010 at the $5^{\text {th }}$ International Conference of Federalism: ${ }^{11}$

Unlike other developmental states [...], the approach here is for massive grassroots mobilisation. You can't have massive grassroots mobilisation on the basis of a national uniform plan. It has to vary not only from region to region but also from village to village, because the circumstances in each village are unique. So the national plan, the national framework, is just that: a framework on the basis of which every village will have to write its own story, but a story that will add up into the national development plan.

Partly because of its ambitious and innovative character, the implementation of the federalist project encountered a few challenges from the very beginning. These included the definition of ethnic groups, the adoption of local languages, and the legitimisation of the new administration in areas where the EPRDF was less rooted, such as Oromia, Amhara and Southern regions. As a result, often the EPRDF had to get actively involved in creating the conditions for decentralisation, with training and propaganda (Markakis, 2011). Easing the capacity constraints at the local level was in the mandate of the Ministry of Federal Affairs, which also ensured the involvement of the central government in regional affairs (Abbink, 2011).

While ethnic federalism was clearly the main feature of the EPRDF period, and indeed it was de facto in place already in 1991, full implementation and operationalisation were rather challenging throughout the $1990 \mathrm{~s}$. The project was then complemented with the woreda-level ${ }^{12}$ decentralisation started in the early 2000 s, and was characterised by more administrative than ethnic salience. This process entailed the multiplication of woredas across the country, and it thus involved a huge increase in local resource needs both in terms of staff and financing.

\subsection{Economic policies in the 1990s}

The Ethiopian economy taken up by the EPRDF in 1991 was in a dire condition (Markakis, 2011). Figure 4 shows that GDP per capita had been decreasing from the mid-1980s. A few years after taking power, Meles Zenawi, aware of the centrality that economic policies would have, started a degree in economics at the Open University in Britain, and instructed cabinet officials and fellow guerrilla soldiers to do the same. He later continued his education at the Erasmus University in Rotterdam - his thesis, titled 'African development: dead ends and new beginnings', completed in 2004, is still a reference document for understanding the economic policies of Ethiopia (Gill, 2010).

In the early 1990s, however, the Government was still dealing with political issues, not least the establishment of ethnic federalism. Partly to ensure Western support and partly to distinguish itself from the previous regime, the EPRDF declared its intent to move towards a market economy, although the real commitment was unclear (Eshetu Chole, 2004). In this context, in the early 1990s the EPRDF started a process of liberalisation and privatisation under the auspices of the international financial institutions. Financial and technical support had already been provided in 1991 by the African Development Bank, the European Community, the World Bank and the International Monetary Fund, which later supported also the Structural Adjustment Programme (SAP) of 1993-96.

One of the sectors to be liberalised, at least partly, was the financial sector, which so far had been dominated by the Commercial Bank of Ethiopia. Reforms in the early 1990s allowed the private sector to engage in banking and insurance, although this was restricted to Ethiopian nationals. The liberalisation also involved the agricultural sector, reintroducing hired labour and eliminating restrictions to plot size (Markakis, 2011). The EPRDF also encouraged capitalist farming and the establishment of larger plots, particularly in the lowland areas (Young,

\footnotetext{
${ }^{11}$ See www.ethiopianfederalism.org.

${ }^{12}$ Woredas are the local level of administration - decentralised level below regions.
} 
1997). However, public land ownership was maintained, and even given a constitutional basis. The need to increase productivity of smallholders and the importance of industrialisation were enshrined in the Agricultural Development Led Industrialization (ADLI), a long-term strategy that entailed a focus on agriculture and which continued to shape development efforts for many years (Alemayehu Geda, 2011).

Privatisation started but implementation was slow, also due to the lack of private investors. This slow progress is part of the reason for delayed payments under the SAP, which after the first tranche of 1993 were frozen for twenty-three months (see figure 6). The privatisation often resulted in the transfer of ownership from the state to members of the party or party affiliates ${ }^{13}$ (Markakis, 2011). Since the role of the party in the economy was formally outside the state proper, the issue did not raise complaints from the international community. A truly private sector therefore remained limited, also due to the lack of faith that the EPRDF had in it as a promoter of development.

Figure 6: Deviations from three-year moving average of grants and tax

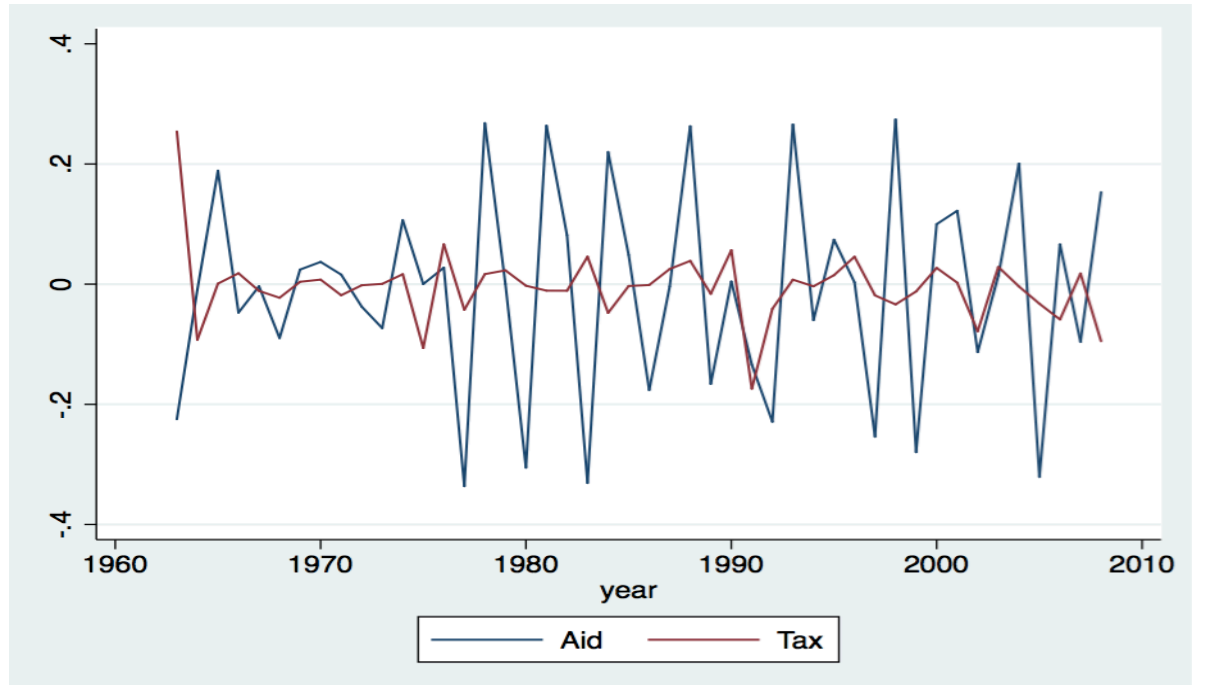

Note: the figure reports deviations from the three-year moving average of the grants and tax series in levels. Source: author's calculations using data from the Ministry of Finance and Economic Development

While some effort was made towards liberalisation, the interviewees with direct experience of this period hold that the process was undertaken reluctantly and half-heartedly. The EPRDF was still essentially anchored to Marxist ideals, and it did not have faith in a purely marketoriented economy. Indeed the limits of the liberalisation process were very clear for the Ethiopian government. A few issues were non-negotiable then, and still remain so, such as public land ownership, the liberalisation of telecommunications and the financial sector. This tendency towards a large role of the public sector will become more clear with the emergence of the idea of a developmental state.

\subsection{The war with Eritrea and the TPLF crisis: 1998-2002}

The late 1990s and early 2000s represented a turning point for the EPRDF, and marked the emergence of its current profile.

In 1998, war erupted with Eritrea over a border dispute, after years of rather peaceful relations. This caused the suspension of aid disbursements to Ethiopia on grounds of a 'peace

\footnotetext{
${ }^{13}$ One example is the Endowment Fund for the Rehabilitation of Tigray (EFFORT) established by the TPLF in 1995. EFFORT was a conglomerate of industrial, financial and service enterprises meant to help the reconstruction of Tigray. Other regions later followed this example, and established similar bodies.
} 
conditionality', based on the view that development aid could not be delivered to a country that was scaling up its military spending, which Ethiopia was indeed doing during the war (Gill, 2010; Markakis, 2011).

While the war was raging the country, bad rains in the area of Wollo and in the Somali region caused acute food shortages. Since aid was not available, or at least was much short of what was needed, the affected people had to sell their assets and thus became even more vulnerable to the subsequent drought (Hammond and Maxwell, 2002). There is little doubt that the war with Eritrea was a major reason for the slow response of donors to what was called an 'averted famine', although many in the affected areas suffered from severe malnutrition and died as a consequence (Hammond and Maxwell, 2002).

A truce was eventually reached in 2000 with mediation from the Organisation of the African Union (OAU) and the United Nations. An agreement was reached on the border issue in 2001 and aid resumed. However, tension with Eritrea remained high, and the two countries suspended all relations.

One of the consequences of the war was the emergence within the party of two factions. The first one, led by Meles and eventually prevailing, was more sensitive to international pressure and was thus in favour of a conciliatory approach that would lead to an early ending to the conflict. The second faction was in favour of a full-scale offensive against Eritrea (Medhane Tadesse and Young, 2003). The war was certainly one of the causes of the 2001 TPLF crisis, but not the only one.

The tension within the party was further exacerbated on the occasion of one of the TPLF's customary evaluations. The main themes of discussion, presented by Meles, were the decaying of the TPLF leadership, the increasing distance from its constituency, and concern over the influence of foreign powers in Ethiopia (Medhane Tadesse and Young, 2003). These were farreaching and delicate themes that sparked a heated debate from which Meles emerged as the undisputed leader (Medhane Tadesse and Young, 2003).

The crisis marked a turning point in the history of the EPRDF for at least three reasons. First, the emergence of a strong single leader implied a shift away from collective leadership and towards centralism. Second, it underlined the need for the EPRDF to improve national legitimacy, thus softening the ethnic discourse. The focus switched from ethnicity to poverty and economic development. This entailed a massive increase in resources for development and service delivery at the woreda level starting in 2001. Notably, devolution of powers to the woreda level had no ethnic salience, as it was a purely administrative process. Third, the attention moved from political to economic issues, in a partial ideological shift. The government was now willing to be integrated in the world economy and to be open to capitalism, which had not been indicated so clearly before. However the EPRDF maintained some key features, such as the central role of the state in the economy, the commitment to federalism, public ownership of land, and support for the peasants (Medhane Tadesse and Young, 2003). Moreover the link between the party and the state strengthened even more after the crisis.

In this context, foreign relations were enhanced as Meles was seen as a moderate moderniser (Markakis, 2011). The role of donors was crucial in determining the fate of the war, and thus in the crisis as well, with the imposition of the peace conditionality. The government coming out of the 2001 crisis was certainly a good ally of the West, but also a more assertive and confident one than donors had become used to during the 1990s.

\subsection{Consolidation and reform}

As the political challenges were overcome, the government could fully focus on economic issues. The underlying ideology for economic policy in the 2000s was that of a developmental state. This concept is largely in line with the idea of revolutionary democracy ${ }^{14}$ that characterised the

\footnotetext{
${ }^{14}$ Revolutionary democracy was the ideology adopted by the TPLF/EPRDF to promote democratisation in Ethiopia and the empowerment of ethnic groups. The concept has its roots in Leninism, though it is infused with
} 
TPLF/EPRDF after the struggle, and that after 2002 was more forcefully opposed to liberal democracy. The ambiguous relation between the idea of a developmental state and opening up to the market economy caused some tension with international donors. However Meles was not willing to compromise, and he remained unpersuaded by the validity of applying liberalism to a developing economy. His view was reinforced by the support of prominent economists like Joseph Stiglitz, who was not only his mentor but also a personal friend (Gill, 2010; Dereje Feyissa, 2011). In 2008, during a two-hour question session following the presentation of his thesis on the developmental state, ${ }^{15}$ Meles reportedly said: ${ }^{16}$

We in Ethiopia very nicely and politely have rejected a number of neoliberal prescriptions given to us, and we have lived to tell the story.

In this context of renewed confidence the government also reappropriated the political space for reform that was largely limited before 2001, as suggested by a top government official with a long experience with the EPRDF. The Civil Service Reform, started in 1996, was revived in the early 2000s. The overarching objective was to create a qualified and technically prepared civil service, including in the area of tax administration (MOFED, 2002). In 2002 a major reform was carried out in the area of taxation, which had received only marginal attention since 1991. The reform represented a major effort to improve revenue mobilisation, which was falling short of the needs stemming from administrative reforms, decentralisation and the re-militarisation carried out during the late 1990s. Notwithstanding the rocky relations with the IMF, the area of taxation was actually one in which there was much agreement, and, indeed, the IMF, along with other donors, played a crucial role in supporting the tax reform (see section 5.6).

The renewed confidence of the EPRDF after the 2001 crisis may also help explain the liberal approach adopted towards the 2005 elections. The run-up to the elections was marked by much fervour, with the emergence of partisan newspapers and publicly broadcasted debates (Markakis, 2011; Gill, 2010). Many interviewees remember the absolute confidence of the EPRDF of winning elections, which were seen more as an opportunity for broad endorsement and fine-tuning than for radical change. The opposition parties, opposed to federalism and supporting more liberal economic policies, eventually lost the elections after a heated debate in which both sides claimed victory. In the months following the elections tension was high, and violence erupted in the streets in November 2005, causing 200 deaths (Markakis, 2011). International donors, particularly the EU, adopted a hard line against the government and the situation quickly escalated into a personal confrontation between Meles and Ana Gomes, the electoral mission's chief observer (Gill, 2010). The political ferment preceeding the 2005 elections was never seen again, with essentially no organised opposition operating in the country since then (Markakis, 2011).

Although the government won the elections, the result was seen as a major blow as the opposition succeeded in getting a substantial number of votes. This shock prompted a moment of reflection and evaluation within the EPRDF leadership. This process resulted in a reinforcement of the developmental state as the main ideology of the EPRDF. In the aftermath of the 2005 elections, it became even more clear that the government's legitimacy would be based on its strong and effective role in development and poverty reduction in the name of the people of Ethiopia. The renewed focus on national development also sped up the move from ethnicity to nationalism already underway in the EPRDF since the early 2000s.

It is in this context that the government engaged in the big push towards GDP growth and economic development that emerged clearly in the 2005 Plan for Accelerated and Sustained Development to End Poverty (PASDEP), and even more so in the 2010 Growth and Transfor-

democratic principles (Abbink, 2011). It postulates the need for a strong vanguard party, ruling in the name of the rural masses, the commitment to the right of self-determination, the intertwining between the party and the state, and their dominant role in politics, the economy and society (Abbink, 2011; Hagmann and Abbink, 2011).

15 "Dead ends and new beginnings" is Meles's thesis, where the concept of developmental state is outlined.

${ }^{16}$ Cited in Gill (2010). 
mation Plan (GTP). The enemy was now poverty, and the nation was called to unite towards its eradication.

Following the developmental state thesis, the government massively scaled up its efforts in infrastructure development. One of the best examples of this is the Great Ethiopian Renaissance dam on the Blue Nile River. Notably this dam, which will be the biggest of its kind in Africa, is fully funded with domestic resources since donors did not want to get involved due to the dispute with other countries regarding the Nile waters. The dam emerged in many interviews as a symbol of Ethiopian independence and pride.

On the agricultural side, progress was made to attract foreign investors into commercial agriculture. Land lease contracts were stipulated in the context of what is internationally labelled 'land grab' or 'the second scramble for Africa'. These contracts entail very low or zero tax rates on profits, and other exemptions are granted for several years since establishment (Markakis, 2011). In the case of both land lease to foreign investors and the construction of dams, the process is largely controlled from the top, thus confirming the growing tendency to centralism.

The big push for development expenditure and economic growth is reflected in GDP figures, which show staggering growth rates, consistently in double digits after the economy recovered from the 2001-2002 drought (see figure 7). Figure 4 shows that GDP per capita doubled from the early 2000s. While these figures are partly justified by the projects and scaling-up of service delivery at the woreda-level, they are also the object of much criticism by the International Financial Institutions (IFIs), as well as academics (Dercon and Zeitlin, 2009). The IFIs have argued that GDP figures are largely inflated, and the continuous confrontation with the WB's former Country Director Ken Ohashi was mentioned several times in interviews.

Figure 7: Growth rate of GDP at constant prices

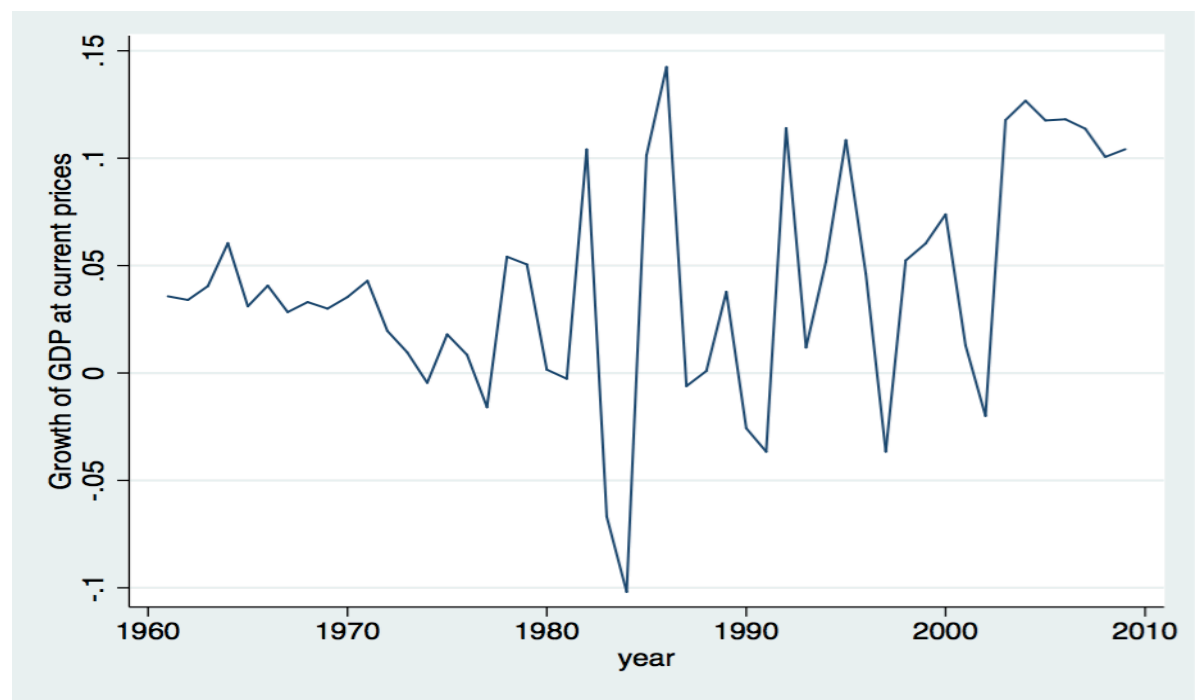

Source: author's calculations using data from the Ministry of Finance and Economic Development

Over this period, it seems that the EPRDF went gradually back to the tradition of centralism that was typical of the previous regimes. The thesis of transformation and continuity developed in Clapham (1988) is therefore picked up again by observers of today's Ethiopia such as Abbink (2011). Moreover Markakis (2011) holds that this tradition of authoritarianism and centralism inherited from the Imperial period is precisely one of the two obstacles that Ethiopia is still to overcome, together with the integration of the lowlands population that are currently at the periphery of the state. 


\subsection{External relations}

Since aid and relations with donors ${ }^{17}$ was a central part of the interviews, this section is largely based on interviews of both government and donor officials.

Since 1991 Ethiopia has received increasing amounts of aid, in the context of development programmes such as the 1991 Emergency Recovery and Reconstruction Programme and the 1993 SAP. As reported in table 1, grants and loans each amount to about 3 per cent of GDP in the EPRDF period. In terms of aid dependency, defined as total aid (loans and grants) as a share of total expenditure, the average in the EPRDF period is 28 per cent (see table 1). Figure 8 shows that aid indeed increased as a source of government funding in correspondence with the SAP. While these figures may seem high, it is worth noting that aid per capita was only 211 ETB per head in 2009/2010 (equivalent to about 7.5 GBP).

Figure 8: Aid dependency: grants and loans as a share of total expenditure

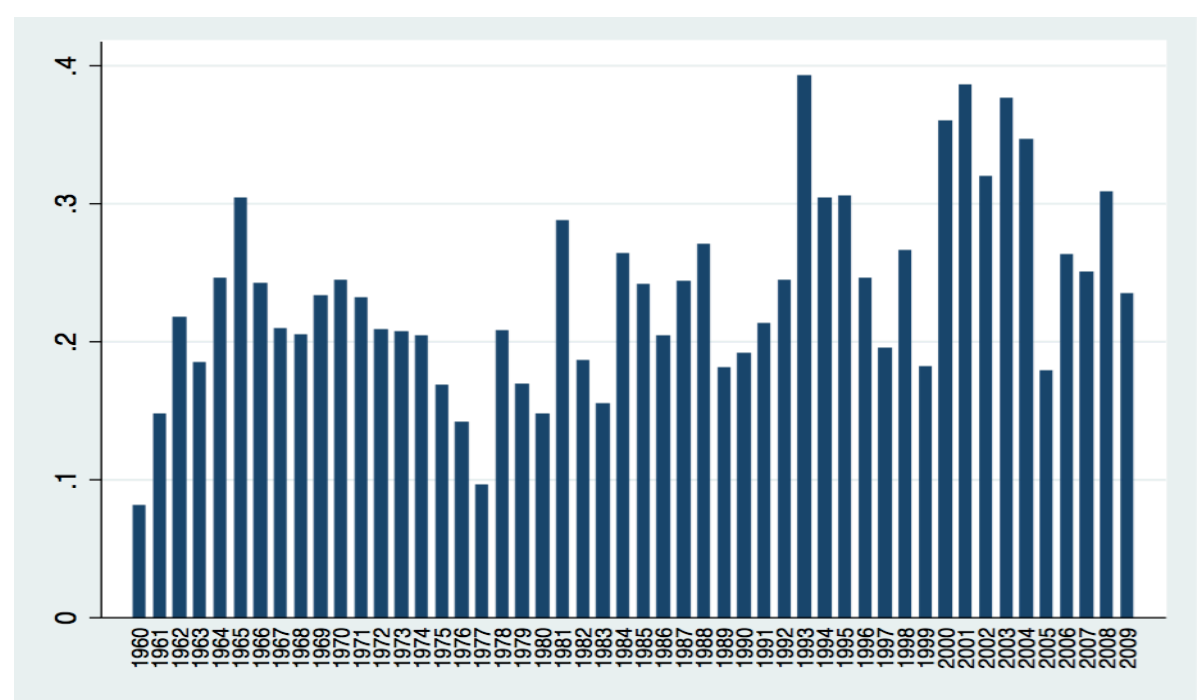

Source: author's calculations using data from the Ministry of Finance and Economic Development

In the 1990s the government engaged in the liberalisation process described in section 5.2 as part of a strategic softening of EPRDF ideology (Dereje Feyissa, 2011). This not only allowed the party to obtain funds for reconstruction and new allies, but also to draw a clear distinction with the Derg, notwithstanding several ideological similarities. Despite the fact that the development strategy of the 1990s was largely dictated by donors, the EPRDF was able to draw clear lines for what it was willing to accept. An interviewee put it rather neatly, dividing policy dialogue in three categories. The first one is the area of agreement, including topics like health and education. The second one is the area of compromise, where ideas proposed by the donors may be adopted even if the government is not really enthusiastic about them as long as they are in line with the government's vision. The third one is the no-go area, and it includes topics like the liberalisation of the financial sector and telecommunications, and the privatisation of land. In this area no compromise was reached even in the 1990s.

The first clear rupture in donor-government relations occurred in 1998, when donors stopped aid to Ethiopia because of the war with Eritrea; this also coincided with the averted famine. This rupture fuelled the Ethiopian government's perception that donors were unreliable and not trustworthy, as they abandoned the country at a time of need. Moreover, relations with

\footnotetext{
${ }^{17}$ Ethiopia has received over the period more multilateral than bilateral aid, with the main multilateral donors being the World Bank (IDA), the UN system (UNICEF, UNDP and WFP for emergency assistance), the European Union and the African Development Bank. The largest bilateral donors have historically been the United States, Japan, Italy and Canada, with also Germany, The Netherlands, Norway and the UK playing an important role.
} 
foreigners were at the centre of the TPLF debate, thus sparking a strong willingness to maintain control and independence over policymaking. The problem of the government was to 'maximise the inflow of resources (so it can finance as much as possible), while giving up as little sovereignty (in terms of control over the policy agenda) as possible' (Furtado and Smith, 2007).

When donors came back to the country in 2000, the approach to development was shifting towards untied budget support, the use of country systems and a stronger focus on ownership (Dereje Feyissa, 2011). The first poverty reduction strategy programme, the Sustainable Development and Poverty Reduction Programme (SDPRP), adopted in the early 2000s, had a strong focus on untied budget support. This is reflected in figure 8, which shows increased foreign presence in the budget at this time; this was sustained by the strong commitment to development of the Ethiopian government, which was providing a positive development story for donors. However this commitment was not the only element attracting donors, and perhaps not the most important one.

The terrorist attacks of 11 September 2001 reinforced the strategic significance that Ethiopia had lost with the end of the Cold War, but that had already been revived by the bombings of the American embassies in Nairobi and Dar es Salam in 1998 (Dereje Feyissa, 2011). With the start of the war on terror, Ethiopia became a crucial ally of the US in a region (the Horn) of political instability and extreme Islamist tendencies. During my interviews with the donor community, even the most technocratic institutions recognised that geopolitical factors are the main determinant of aid in the country. An interviewee put it rather clearly: 'donors want to stay in Ethiopia for two reasons: first, development objectives and poverty reduction; second, strategic interests. But really, the order is more realistically reversed.' This view is confirmed in virtually all interviews within the donor community; it is also supported in Furtado and Smith (2007) when they state that:

Changes in the level of donor assistance to Ethiopia have been driven overwhelmingly by political and geopolitical considerations ... These factors, rather than anything the government has consciously done to manage the aid agenda, have largely determined the level of aid inflows.

As capacity constraints were still a major issue both in the centre and in the periphery, the US\$483 million Public Sector Capacity Building Program (PSCAP) was launched in 2004. PSCAP was aimed at improving public service delivery at all levels of the public administration, increasing citizen participation, and enhancing good governance and accountability in the public sector. One of its six workstreams is focused on taxation, and it entailed reinforced collaboration with donors on tax reform and revenue mobilisation - for example including twinning programmes between tax authorities in Ethiopia and the UK.

A second rupture occurred in 2005, when donors condemned the post-election violence and withdrew untied budget support, which by that time was planned to be scaled up from US $\$ 375$ to US\$500 million (Furtado and Smith, 2007). In a climate of renewed distrust and tension, donors rather quickly came up with a solution in the form of a project, the Protection of Basic Services (PBS), which was going to become the largest of its kind in Africa. The largest component of PBS provides for service delivery at the local level through the government's financial management system, and particularly through the block grant to the regions. PBS more recently funded a project aimed at increasing transparency and accountability that entailed the publication of the local administration's budget in public places, such as churches, mosques and kebeles. Disclosure and dissemination of budget information was also supported by the use of media such as TV and radio, as well as budget literacy training for citizens at the woreda and kebele level.

An official from a major donor agency noted that, far from being a punishment for the 2005 events, PBS turned out to result in more and better aid for Ethiopia. Not only did the programme reinforce the local service delivery that the government was pursuing strongly as a means to reduce poverty and to increase legitimacy, but it also caused the disappearance of 
donors (in terms of visibility) as all the improvements at the local level were seen as achievements of the government. In addition, the increased focus on service delivery meant a closure of the arenas for policy dialogue on broader macroeconomic issues, which had been present under untied budget support. The government welcomed this development, which donors might not have fully foreseen.

As a result of the ruptures in donor-government relations, 1998 and 2005 being only two of them, ${ }^{18}$ and the the long tradition of independence and statehood, it is not surprising that donors in Ethiopia have little influence over policy and the development agenda. This not only emerged during the interviews, but is also confirmed by several scholars (Abbink, 2011; Furtado and Smith, 2007). For example, it is recognised by donors that the conditionality provided under PBS is hardly enforced or enforceable, instead being rather soft. Moreover the assertiveness of the government towards traditional donors is certainly encouraged by the emergence of new donors and most notably China.

Generally the Ethiopian government over the years has shown a great degree of ownership over the development process, which has somehow put donors in an uneasy situation. On the one hand, they would like to have a voice in policymaking. On the other hand ownership is precisely what donors wanted to promote under the Paris Declaration on Aid Effectiveness, amongst other related processes. They are therefore not in a position to criticise the government for taking the ownership that they should encourage.

\subsection{Tax revenue mobilisation}

The new government in 1991 was able to take over the remains of the administrative apparatus relatively quickly. Both officials and observers consistently confirmed that the state was actually functioning throughout the transition with as little as one week of administrative blackout. However the fiscal situation inherited from the Derg was disastrous. Not only was revenue low and decreasing for three years in a row, but also arrears on debt payments kept accumulating. A top government official suggested that, at the beginning of the EPRDF period, debt was a central concern of the new government, more pressing than increasing revenue. Indeed the government succeeded both in reducing deficit (see figure 3) and in mobilising revenue, which in 1992 increased by 36 per cent and was still at a sustained double digit rate until the war with Eritrea in 1998. These great improvements in fiscal policy were partly due to the very low level of tax collection under the fiscal collapse of the Derg, which was relatively easily reversed with the start of the new regime; and partly to the fact that the EPRDF by the early 1990s had already gained good control of many regions in Ethiopia, where the Derg had almost no authority anymore. Moreover the dismantlement of the Derg's huge military apparatus decreased expenditure substantially, therefore contributing to decreasing the deficit.

Although progress was made in increasing revenue from the historical lows of the Derg, the EPRDF performance remained weak for a number of reasons. First, revenue generation had certainly suffered from the secession of Eritrea, which was more industrialised than Ethiopia, and from the dismantling of nationalised firms. Moreover, tax revenue mobilisation was constrained by the desire to keep the fiscal burden on peasants low, as they were the main constituency of the EPRDF (Young, 1997). Last, but not least, the 1990s were a period of great political change, as noted in section 5.2, thus limiting both the capacity and the policy space for reform. Tax policy was no exception, and a high-ranking government official described the EPRDF's attitude towards it as relaxed in the 1990s. The reasons for this, he explained, were the low

\footnotetext{
${ }^{18}$ For example, the Ethiopian government had several disagreements with the IMF, and notably is not a "programme country' of the IMF, which is therefore only covering a surveillance and advisory role in the country. The reason for this, emerging in the interviews, is that Ethiopia was not willing to take the conditions and pressure on policymaking that an IMF loan would entail. Disagreement also emerged when donors refused to fund big hydroelectric projects such as the Renaissance Dam, which is seen as a centrepiece of the country's development strategy.
} 
expenditure needs ${ }^{19}$ and the limited capacity to implement programmes, by which he also meant political space. Indeed the top marginal tax rates were kept at the Derg's levels until 1994, at 59 per cent on businesses income and still 89 per cent on personal income (Eshetu Chole, 2004).

However, a few policy changes were carried out by the EPRDF in this period. Proclamation 107/1994 amended the previous income tax law (Proclamation 173/1961 and amendments), and brought maximum marginal tax rates to 35 per cent. In two separate proclamations in 1995 and 1997 the tax on rural land and agricultural income was reviewed, introducing tax exemptions for two consecutive five-year periods for agricultural investors (Alemayehu Geda and Abebe Shimeles, 2005). These were adjustments of tax law rather than major reforms, with the other relevant tax event being the introduction of the turnover tax, whose implementation, however, was phased in over a few years.

The war with Eritrea further distracted the government's attention from economic issues, and it captured virtually all the national efforts until 2000. Observers close to the government remember that little or no attention was given to the economic situation at that time, let alone fiscal policy. Revenue generation stagnated between 1998 and 1999 (see figures 5 and 6), and the deficit increased to a historical high (see figure 3). However the increase in the deficit was also due to the food shortages that the government had to meet with increased borrowing, as foreign aid was not available until the end of hostilities in 2000.

It is in the early 2000s, in the context of a more peaceful political setting and a renewed commitment to developement, that tax revenue mobilisation became a higher priority for the government. Revenue needs increased massively: the increased militarisation achieved during the war was going to be sustained, while the woreda-level decentralisation and the infrastructure projects implemented in the context of a developmental state also required huge resources. Since the delivery of services at the local level was becoming a basis for legitimacy, finding resources for development plans became even more pressing.

It is in this context that the major tax policy reform of the EPRDF period took place in 2002. The reform entailed both an income tax proclamation (Proclamation 286/2002) and a law on indirect tax (Proclamation 285/2002). The former further decreased the higher marginal income tax rate from 35 per cent to 30 per cent and introduced various deductions for the calculation of business profits. In addition it included Tax Identification Numbers (TIN) that had to be assigned to all businesses and individual taxpayers in urban areas. A generous set of incentives for investment, both foreign and domestic, was provided for. Amongst these were tax holidays that include a regional development element, providing for longer periods of exemption for investments in more remote regions.

The main innovation of the second proclamation was the introduction of the Value Added Tax (VAT) starting from 2003, which was meant to substitute previous indirect taxes (i.e. sales and turnover tax). Other taxes were also introduced in the early 2000s, such as the surtax on imports, the withholding tax on income, and the interest tax, while taxes on exports were brought to zero starting from 2003.

Implementation of the reform however was difficult, particularly as far as VAT and TIN are concerned. Indeed figure 5 shows that the tax share (of GDP) actually decreased following the reform. This decline was explained by government officials as implementation problems due to the lack of taxpayer's collaboration and capacity constraints in the government. Not only did the reform find resistance from taxpayers, but also from the tax administration that, a top government official explained, was not happy about improved systems of collection that would undermine the unofficial benefits that tax officials were able to extract from a mismanaged system. A foreign observer noted that the government, rather optimistically, hoped that the business sector would come forward upon the introduction of TIN and VAT, but instead it backed off through tax evasion and avoidance.

\footnotetext{
${ }^{19}$ The great demilitarisation process following the fall of the Derg was surely a major determinant of decreased expenditure needs.
} 
Interestingly a top government official noted that while the rural sector had a strong tradition of tax compliance, notwithstanding its low contribution to revenue, urban areas did not. What is sometimes referred to as the 'modern sector', to distinguish it from agriculture, had a relatively short history in Ethiopia and it had little compliance culture, not fully perceiving the need to contribute to the government's revenue. The disengagement of the EPRDF from the private sector, at least in the 1990s, might have contributed to reinforcing this problem.

The government of Ethiopia in the 2000s was fully aware that domestic financing had to play an increasingly important role with respect to foreign resources. Not only was foreign assistance insufficient to cover the increasingly ambitious development plans, but also donors were increasingly seen with suspicion and distrust, particularly after the experience of the war with Eritrea. Aid had proved to be volatile (see figure 6), and the donors' wish to influence the policy dialogue was more and more unwelcome. A few government officials I interviewed noted that aid is neither sustainable nor predictable, also due to the determination of the Ethiopian government to set its own development agenda that donors may not always agree upon (e.g. Great Renaissance Dam). Domestic resources instead are perceived to be under the control of the government, thus offering a more stable source of revenue and, perhaps more importantly, one over which the government has undisputed decision power. Figure 6 shows clearly that tax revenue is less volatile than aid.

This is the spirit with which the government engaged in the administrative tax reform of 2008 and 2009. First of all, tax administration was unified under the Ethiopian Revenue and Customs Authority (ERCA), which was taking over the activity of the Federal Inland Revenue, the Ethiopian Custom Authority and the National Lottery Administration, previously controlled by the Ministry of Revenue. This greatly improved the status and effciency of revenue administration, which was now managed under a single and independent authority, governed according to special rules aimed at preventing corruption and mismanagement. ${ }^{20}$ Secondly the implementation of VAT was complemented with the introduction of registration machines that would record all firms' transactions, and report them directly to the newly established ERCA. Finally, a campaign against tax evasion included the imprisonment of evaders and a policy of 'naming and shaming' them in the media. The media was also used for tax education campaigns, which would explain the need to pay tax and contribute to the government's budget to fulfill the development plans.

The reforms of 2008 and 2009 succeeded in increasing tax revenue, with the growth rate falling slightly short of 50 per cent in 2009 (49.4 per cent). This trend is largely in line with the ambitious revenue goals of the 2010-2015 development plan, the GTP, that foresees an average annual growth rate of 24 per cent, against an annual GDP (at constant prices) growth rate foreseen at 11 per cent. While some point to a tax buoyancy problem, ${ }^{21}$ the government's view is that the revenue-generating potential of the Ethiopian economy is not tapped, and therefore large margins still exist. The increase in tax revenue has been largely achieved with an increase of the tax base rather than changes in the tax rate, by fighting evasion, improving compliance and administrative capacity, as well as bringing more taxpayers into the tax net. The target for 2015 is for tax revenue to reach 15 per cent of GDP, from the initial 11 per cent. This is a target that most donors, and more obviously all government officials, considered within reach at the time of interviews. The GTP also sets a medium term goal for Ethiopia to become a middle-income country and to become independent from foreign aid, both ambitious goals that find widespread support and commitment amongst government officials.

Despite the great efforts to increase tax revenue, the tax share in Ethiopia, at 11 per cent of GDP in 2009, remains lower than the average of low-income African countries of 15 per cent. This is due to a few important constraints that are mostly related to a small tax base. They

\footnotetext{
${ }^{20}$ For example, ERCA employees have higher salaries than those in other public bodies.

${ }^{21}$ Tax buoyancy is the elasticity of revenue with respect to national income, measured as the product of the elasticity of revenue to the tax base and the elasticity of the tax base to income.
} 
include both low income and the large share of the agricultural sector.

On the one hand, at low levels of income it is difficult to extract revenue. As a local economist noted, below a certain threshold income is either exempt or taxed very little. As development occurs, more people will start paying tax, and they will also pay more as they move to higher tax brackets. On the other hand, the agricultural sector still contributes about 40 per cent of GDP, and 80 per cent of the Ethiopian people live in rural areas. This sector is highly dominated by smallholder agriculture that is difficult to tax for technical reasons, exacerbated by the ties of the EPRDF with rural constitutencies. The tax on land remains almost negligible, and investors can benefit from generous exemptions on business profits tax. High-level government officials are aware that agriculture contributes little to tax revenue, and that it may be an area for future reform.

Other major constraints consistently mentioned in virtually all interviews are capacity and compliance. The two are obviously related, as low compliance is hard for the government to tackle if capacity constraints limit enforcement. In addition, a few interviewees noted that while the top tax rate is a reasonable 30 per cent, the threshold for falling in the top bracket is very low - at 5,000 Birr a month, roughly equivalent to 170 GBP. More and more people are falling into that bracket, which might have been appropriate in the past but may need revision today. The relatively high tax burden of income was reported in interviews as a factor increasing tax avoidance. International tax competition and fiscal benefits for investors are a further constraint to tax revenue mobilisation. It is noted by a few observers that ad hoc agreements with investors imply fiscal benefits that are difficult to track, and that should be more strictly regulated. Finally, the GDP figures in the denominator may be responsible for the low tax share, as inflated GDP growth would result in an artificially lower tax share. ${ }^{22}$

Last but not least, many interviews pointed to the importance of private sector companies that carry out large investment projects and have strong links with the state and the party. They suggested that a full assessment of fiscal discipline should take into account these actors, who may be accumulating debt. Unfortunately data on this sector is not readily available, and therefore this analysis focuses only on the public budget.

\section{Implications for tax and aid: four underlying factors}

The fiscal history of Ethiopia outlined in the previous sections allows the identification of at least four related underlying factors in Ethiopian history and culture that deeply influence the relation between taxation and aid. While these factors have been present throughout Ethiopian history, they emerged more clearly in the 2000s.

Before describing in detail the underlying factors, however, it is useful to note that during the interviews I asked all interviewees if they thought aid and tax are treated as substitutes in Ethiopia. The vast majority of them were convinced that aid does not have a disincentive effect on tax, and that the two variables are not treated as substitutes. When asked about the nature of the relationship between aid and tax, many interviewees pointed to a positive relation based on the role of aid in easing the capacity constraint of the government and in supporting economic development.

Only a few interviewees thought that either aid has no effect on tax or has a negative one. However even they agreed on the possible channels for a positive effect, namely capacity and development, and on the validity of the underlying factors presented here in the Ethiopian context. Indeed the discussion so far has shown that Ethiopia has always had foreign advisors

\footnotetext{
${ }^{22}$ The level of GDP may be understated in many developing countries due to the difficulty of measuring some sectors and to informality. It is beyond the scope of this paper to assess whether this is the case in Ethiopia, but systematic underestimation should not alter the time series analysis. In the case of GDP growth rates, there was a debate between the government and the international financial institutions on the credibility of double digit growth rates.
} 
on tax matters, thus making the capacity channel particularly plausible.

The underlying factors are discussed in the following paragraphs; they are certainly related and in some cases even overlapping concepts.

\section{Tradition of statehood and continuity}

This paper has shown that the long tradition of statehood, interrupted by only a few years of Italian invasion, is one of Ethiopia's most valuable assets. Bahru Zewde, a Professor of History at Addis Ababa University, holds that transitions in Ethiopia were always characterised by administrative continuity, and that during the transition of 1991 Ethiopia remained without a government for only one week. ${ }^{23}$ The presence of a strong state and administrative apparatus certainly allowed the Derg and the EPRDF to undertake, within a few months of their establishment, radical reforms such as, respectively, the land reform and ethnic federalism.

In addition to the administrative apparatus, continuity also refers to the culture of power and the political environment. Many scholars agree that the way authority is exercised has changed little in Ethiopian history, although certainly much has changed otherwise. Clapham (1988) notes that the following description of the Ethiopian leader, used to describe the Emperor, fits Mengistu very well too.

The leader was required to be both omnipresent and omnicompetent, capable of intervening at will in the smallest details of any aspect of administration, and his personal involvement was normally essential where any innovation was involved.

This quote may well describe the late Prime Minister Meles Zenawi as well, who was reportedly fully involved in decision-making in virtually all areas of policy. Indeed Abbink (2011) argues that the thesis on transformation and continuity developed by Clapham (1988) still holds in contemporary Ethiopia. Many observers interviewed in the context of this research agree with that view, although under the EPRDF the tendency towards centralism developed mostly in the second decade of its rule (see section 5.4).

This political culture is not confined to the leadership, and it would be simplistic to think that it is only imposed from the top. Instead it is largely embedded in popular culture, as shown in Lefort's research in rural Ethiopia in the run-up to the 2005 elections (Lefort, 2007). The author shows that peaceful electoral competition was inconceivable in rural areas, with peasants concerned about voting for the winning side to ensure their welfare and even their survival. In their view, the fact that the opposition was able to campaign freely in 2005 meant that the government had abdicated (Lefort, 2007). Along similar lines, Young (1997) notes that the lack of transparency in the first years of EPRDF rule was criticised much more by foreigners than by Ethiopians.

Finally continuity can be observed also in aid, at least in terms of flows. American aid kept flowing into socialist Ethiopia for a few years after the 1974 revolution, and when it was withdrawn it was largely compensated with European and Soviet assistance. The EPRDF had already started talks with donors even before it took power in 1991, so that foreign assistance was ensured for the new government without much disruption. While aid flows are relatively resilient to regime changes, the type of aid changed. Interviews pointed to a certain similarity between aid under Haile Selassie and the EPRDF, while the situation was reportedly very different under the Derg. However these differences are due more to the nature of the regime in power than to variations in donors' approach, linking this discussion to the next underlying factor.

Therefore Ethiopia has experienced at least two important transitions, particularly in 1974 and 1991, entailing radical changes. The great economic, social and institutional developments in the country need to be recognised. However a large degree of continuity is also identifiable in the country, and this can be considered both a challenge and a valuable asset. A challenge, because

\footnotetext{
${ }^{23}$ From Professor Bahru Zewde's keynote lecture on the 'Dynamics of political succession in Ethiopia' at the $18^{\text {th }}$ International Conference of Ethiopian Studies on 1 November 2012 in Dire Dawa, Ethiopia.
} 
the traditional political culture represents an obstacle to pluralism and democratisation. An asset, because the state is strong and capable of pursuing a fully-owned vision for development.

\section{Independence and national pride}

The tradition of independence in Ethiopia is a major source of national pride and a central element of the Ethiopian character. Independence from colonial powers meant that Ethiopia always interacted with Western countries as a peer, and when it entered the international arena it did so as a sovereign country. In his speech at the League of Nations in 1936, Haile Selassie was the first African leader to hold the West accountable for the atrocities of colonialism. The Emperor famously warned Western countries that 'God and history will remember your judgment', as they were failing to protect Ethiopia's sovereignty, thus implicitly being accomplices to the Italian invasion.

A sense of 'having to stand on its own feet' grew in Ethiopia, fuelled by the fact that foreign aid has historically been low in the country partly due to the lack of a colonial patron (see section 3.4). As the aid industry developed and colonialism became less and less influential, Ethiopia started receiving more aid and attention. However it kept the initial spirit, and the presence of this rhetoric today was reported by an observer close to the government: 'Ethiopia could stand on its own feet in the past and it can still do it today'.

This sentiment translated into policy in two ways. A first implication of a fiscal nature: greater importance is attached to reliance on domestic, rather than foreign, revenue. Indeed all government officials interviewed recognise that aid is only an acceptable source of finance in the short run, but not in the long run, thus the goal of reaching aid independence in the GTP. Donors involved in PBS report that Ethiopia consistently overperforms in terms of the domestic revenue mobilisation requirements embedded in PBS, an element explaining the decreased aid dependence of the post-2005 period (see figure 8). This is not because of donors' conditionality, but because increased revenue generation is a top priority of the government. In fact an official from a major donor agency noted that PBS donors would have no credible way to enforce conditionality on revenue generation, as strict targets are not set.

Second, independence translates into a strong ownership of the policy agenda. This is particularly evident from the discussion of the EPRDF period (see section 5.5), but there is also little doubt as to who was setting priorities under the Derg. While Western donors had little or no voice over the policies of the socialist regime, the USSR benefited only from a little more influence due to the natural alignment of Derg's policies with the ideology of the Soviet bloc.

Independence and ownership therefore resulted in little space for donor influence in the country. Even when the EPRDF was more compliant in the early 1990s, it was very clear about the areas where no compromise was acceptable. The desire to be free from conditionality was cited as the main reason for Ethiopia to decline an IMF loan, thus never becoming a programme country. This also explains the importance of new donors, who not only allow the country to be more flexible in the choice of sources of financing, but also typically impose less policy-related conditionality.

The attitude towards aid in Ethiopia is deeply shaped by this sentiment of independence and pride. In the words of an interviewee, 'aid is a bitter medicine, not a sweet candy'. As emerged in at least two interviews, it is a shame for Ethiopians to have to rely on foreign money to feed their population. This sentiment clearly emerges from Meles Zenawi's millenium speech: ${ }^{24}$

While we can justly be proud of the fact that every generation of Ethiopians during those centuries have paid in blood to maintain our independence, we cannot but feel deeply insulted that at the dawn of new millennium ours is one of the poorest countries in the world. Over the course of our second millennium we have gone from being one of the most advanced nations on earth to that of being one of the poorest.

\footnotetext{
${ }^{24}$ Extract from Meles Zenawi's speech on the occasion of the new Ethiopian millenium celebrations in 2007, available on www.nazret.com.
} 
Throughout this process we have not been colonised by any foreign nations and hence we have always been the authors of our destiny, both our successes and failures. [...] A thousand years from now, when Ethiopians gather to welcome the fourth millennium, they shall say that the eve of the third millennium was the beginning of the end of the dark ages in Ethiopia. They shall say that the eve of the third millennium was the beginning of Ethiopian renaissance.

All this is crucial to understand why the Ethiopian government might not just treat aid and tax as substitutes in an opportunistic manner, as deeper historical and cultural aspects are at work here.

\section{Political commitment and ambition}

Linked to the issue of independence and national pride is the continued commitment of Ethiopian governments to development. While the EPRDF is the first Ethiopian government to make development its foremost objective, a closer look at history as well as the interviews reveal that such a commitment was already present before. The discussion on the commitment to development clearly is not meant to overshadow events such as the Red Terror or the failure of the Imperial regime to tackle the 1973 famine, which killed tens of thousands of people. It is rather one of many elements emerging from Ethiopian history, which is relevant for this research.

While the commitment to development under Haile Selassie has sometimes been described as a mere façade (see section 3.5), the Imperial development plans are probably the first ones in Africa, and the government at the time took practical steps to increase revenue to fund a growing public administration (see section 3.3). In his speech at the League of Nations in 1936 the Emperor declared:

For 20 years past, either as Heir Apparent, Regent of the Empire, or as Emperor, I have never ceased to use all my efforts to bring my country the benefits of civilisation.

As far as the Derg is concerned, a few interviews and informal conversations surprisingly pointed to an underlying commitment of the military government as well. However, they argue, the military regime was not able to pursue this commitment for two reasons. First the Derg had no capacity to implement such a plan, as it was largely composed by military forces with little understanding of economic policy. An interviewee also noted that the training for governemnt officials at that time was largely provided by the USSR, and it was of lower quality than that provided by Americans under Haile Selassie. Secondly the Derg was too occupied with repressing the continuous challenges and opposition it faced, thus not being able to engage in development. While this is only the view of a few Ethiopians, it was fairly consistent across interviewees with different backgrounds. What is written in history is that the Derg came to power with a socialist agenda based on land redistribution and modernisation, as opposed to the exploitative feudal system. In addition, the most serious attempt of the Derg to engage in a development plan was largely spoiled by the 1984 famine. This made its implementation very difficult, even assuming there was a genuine commitment to it.

However it is certainly under the EPRDF that the commitment to development became more prominent and central in the policy agenda. The TPLF's, and later EPRDF's, ideology has always been linked to the struggle for development in rural areas, and the leadership is highly committed to it, as confirmed in all interviews. The ambitious development plans of the last decade are largely in line with this commitment. Moreover the fact that the government is delivering at the local level (through the woreda-level decentralisation and PBS) is helping tax compliance, as the people start seeing a return for their tax payment, in what might be seen as an embryonic and implicit form of social contract.

The ambition, sometimes deemed excessive, and the commitment of the Ethiopian government deeply shape the aid-tax relation. As a top government official noted: 
We want to increase the revenue as much as possible. Then if we get foreign aid, we can add it [to domestic revenue] and it will give us the room to expand our project. [...] If you don't have any vision, then maybe substitution will work, [but not] if you have a vision, as we do, to reach middle income level.

On the contrary, the fact that aid is available makes the ambitious government plan possible because now the resources are available, matched with domestic ones, to deliver it. Projects that would have taken a long time to be financed can now be actually realised with joint domestic and foreign resources. In other words, there seems to be excess demand for funds in Ethiopia. In this context aid and tax are complementary, rather than substituting for each other.

\section{Taxation and aid: relative costs}

The last underlying factor is the relative cost of tax and aid, which is sometimes cited as the reason for substitution. In particular, the argument goes, when governments have to decide how to finance their plans they will first choose aid and then fill the gap with as little tax as possible. This may be the result of a higher political cost of tax whereas aid is 'free' money. This argument is particularly ill-grounded in the Ethiopian case, for at least two reasons.

First, I have shown that aid in Ethiopia is not free, and conditionality and aid dependence represent a heavy burden for leaders. Mengistu was wary of his leadership appearing to be dependent on foreign actors, which would have undermined his image as a strong national leader (see section 4.2). This sentiment is even stronger under the EPRDF, especially after the 2001 TPLF crisis when foreign influence played a crucial role, and was one of the areas of criticism towards the faction led by Meles (see section 5.3).

As far as conditionality is concerned, the interviews revealed that conditions on economic policy, including revenue performance, are not stringent nor really enforceable in Ethiopia. Indeed donors seem to be reluctant to leave the country or to stop aid because of economic conditions, although they may be the cause of delays in disbursement. However conditions are still in place, sometimes more nominally than substantially, and donors are present in the country and seeking dialogue and policy influence, particularly on policies that directly affect large development projects. Moreover, there is a feeling that aid cannot be granted for all the projects that the government wants to embark on, as experienced in the case of the dam project.

The issue of delayed disbursement relates to another element often cited by interviewees: aid predictabilty. At least two top government officials noted explicitly that it is very difficult to make plans based on aid because it is an unpredictable and unreliable source of revenue. They argue that this became ever more clear after the 2005 elections. Another interviewee observed that it is dangerous to rely heavily on an unpredictable source of financing like aid for the huge development projects of Ethiopia. That, he argued, makes the country too vulnerable, as these projects are of foremost importance. This links back to the example of dams, widely cited as an example of projects that donors are not willing to fund though they are central in the government's strategy.

The second reason is related to the cost of raising tax. I asked questions about the political cost of increasing tax revenue in many interviews, and the general consensus, both on the donor and government side, is that such a cost is not a big concern. First of all, the government is acting mainly on expanding the tax base, including fighting evasion and expanding the tax net. Tax rates, on the other hand, have only been decreased under the EPRDF. This generates solid grounds for the government to argue that the increase in tax revenue is essentially fair and aimed to bring everyone in the tax net to contribute their fair share. It is a matter of equality that everyone has to pay tax, and this reasoning is also being promoted with tax education campaigns and increased dialogue on taxation at the kebele level.

In addition, the long tradition of centralisation and statehood is playing an important role. The Derg, for example, was able to extract revenue because the population would generally comply with its authoritarian nature, particularly after the experience of the Red Terror. Even 
during the Imperial regime, a top official noted, people in rural areas were used to paying tax. Failing to do so would be an act of dissent and, he explained, nobody would dare. Even if landlords could exert some resistance to paying tax (see sections 3.1), peasants did not have the power to do so. This legacy clearly remains in today's Ethiopia, although the culture of compliance is not as rooted in urban areas. While the perceived high tax burden creates some discontent amongst businesses and individuals, it seems far from providing the basis for serious uprising, particularly in the context of slow progress on democratisation and pluralism. The government's view is that the fiscal burden is generally not a concern since the economy is growing fast and the full revenue potential is still not tapped.

Finally, the great political and economic importance of the EPRDF's development plan is at work again here. A senior official in a major donor agency noted that the cost of increasing tax revenue is still much lower than the cost of not delivering the plan; other interviewees also talked along these lines, although less explicitly.

\section{Conclusion}

This paper reviewed Ethiopian fiscal history over the period 1960-2010, focusing on domestic revenue and aid, in a more comprehensive way than other studies. In this sense it represents a contribution to the literature. More specifically, the analysis shows that in Ethiopia there does not seem to be a substitution effect between tax and aid, because of four underlying factors emerging from the historical facts and events presented throughout the paper. The analysis of the EPRDF period, in particular, shows how the factors that are present throughout the whole period considered are developed more consciously and clearly in the political discourse of the 2000s.

The analysis also offers an overview of the political economy underlying the observed variations in fiscal variables, thus shedding light on the main drivers of tax revenue mobilisation at various points in the recent history of Ethiopia. In line with other African countries' experience, the small contribution of agriculture to tax revenue emerges throughout the period as a key factor, while trade has historically been a sector where substantial revenue has been generated. However there are also factors related to the specific political and economic dynamics in Ethiopia, such as the strong drive towards federalism in the 1990s, and the increasing commitment and involvement of the Ethiopian government in economic development in the 2000s.

This analysis fills a gap in the literature by presenting a consistent and comprehensive reading of Ethiopian economic history that is geared towards tax mobilisation and aid. Moreover, by showing the importance of social, cultural and economic factors in defining the aid-tax relationship, it underlines the value of complementing a quantitative analysis with in-depth understanding of the historical, political and economic context. In this sense this paper represents a stepping stone for further country-level economic analysis on Ethiopia. 


\section{References}

Abbink, J. (2011). Ethnic-based federalism and ethnicity in Ethiopia: reassessing the experiment after 20 years. Journal of Eastern African Studies 5(4), 596-618.

Alemayehu Geda (2011). Macroeconomic performance in post-Derg Ethiopia. Northeast African Studies 8(1), 159-204.

Alemayehu Geda and Abebe Shimeles (2005). Taxes and tax reform in Ethiopia, 1990-2003. Research paper 2005/65, UNU-WIDER.

Bahru Zewde (2008). Society, state and history: selected essays. Addis Ababa University Press.

Brietzke, P. (1976). Land reform in revolutionary Ethiopia. The Journal of Modern African Studies 14, 637-660.

Chege, M. (1979). The revolution betrayed: Ethiopia 1974-77. The Journal of Modern African Studies 17, 359-380.

Clapham, C. (1987). Revolutionary socialist development in Ethiopia. African Affaires 86, $151-165$.

Clapham, C. (1988). Transformation and continuity in revolutionary Ethiopia. Cambridge University Press.

Clapham, C. (1989). The state and revolution in Ethiopia. Review of African Political Economy (44), 4-17.

Cohen, J., A. Goldsmith, and J. Mellor (1976). Rural development issues following Ethiopian land reform. Africa Today 23, 7-28.

Dercon, S. and A. Zeitlin (2009). Rethinking agriculture and growth in Ethiopia: a conceptual discussion. Mimeo.

Dereje Feyissa (2011). Aid negotiation: the uneasy "partnership" between the EPRDF and the donors. Journal of Eastern African Studies 5, 788-817.

Economic and Political Weekly (1978). Revolution and counter-revolution in Ethiopia. Economic and Political Weekly 13, 461-472.

Eshetu Chole (1984). Towards a history of the fiscal policy of the pre-revolutionary Ethiopian state: 1941-74. Journal of Ethiopian Studies 17, 88-106.

Eshetu Chole (2004). Underdevelopment in Ethiopia. OSSREA.

Furtado, X. and W. J. Smith (2007). Ethiopia: aid, ownership and sovreignty. GEG working paper 2007/28, Global Economic Governance Programme.

Gilkes, P. (1975). Ethiopia - a real revolution?, the world today. The World Today 31, 15-23.

Gilkes, P. (1982). Building Ethiopia's revolutionary party. MERIP reports.

Gill, P. (2010). Famine and foreigners: Ethiopia since Live Aid. Oxford University Press.

Griffin, K. (1992). The economy of Ethiopia. The Macmillan Press.

Hagmann, T. and J. Abbink (2011). Twenty years of revolutionary democratic Ethiopia, 1991 to 2011. Journal of Eastern African Studies 5, 579-595. 
Hammond, L. and D. Maxwell (2002). The Ethiopian crisis of 1999-2000: lessons learned, questions unanswered. Disasters 26, 262-279.

Keller, E. J. (1981). The revolutionary transformation of Ethiopia's twentieth century empire. The Journal of Modern African Studies 19(2), 307-335.

Keller, E. J. (1985). State, party and revolution in Ethiopia. African Studies Review 28(1), $1-17$.

Lefort, R. (2007). Powers - mengist - and peasants in rural Ethiopia: the May 2005 elections. Journal of Modern African Studies 45, 253-273.

Levine, D. (1961). Haile Selassie's Ethiopia: mith or reality? Africa Today 8, 11-14.

Markakis, J. (1989). Revolution in Ethiopia: 15 years on. Review of African Political Economy (44), 1-3.

Markakis, J. (2011). Ethiopia: the last two frontiers. Eastern Africa Series. James Currey.

Markakis, J. and N. Ayele (1977). Class and revolution in Ethiopia. Review of African Political Economy (8), 99-108.

Mascagni, G. (2014). Aid and taxation: Evidence from Ethiopia. Working Paper 73-2014, University of Sussex, Department of Economics.

Mascagni, G. (forthcoming, 2016). Aid and taxation in Ethiopia. Journal of Development Studies.

Mascagni, G. and E. Timmis (2014). Fiscal effects of aid in Ethiopia: Evidence from CVAR applications. CREDIT Working Paper 14/06, University of Nottingham.

Medhane Tadesse and J. Young (2003). TPLF: Reform or decline? Review of African Political Economy 30(97), 389-403.

Mengisteab, K. (1990). Ethiopia: Failure of land reform and agricultural crisis. Greenwood Press.

MOFED (2002). Ethiopia: sustainable development and poverty reduction program. Ministry of Finance and Economic Development, Federal Democratic Republic of Ethiopia.

Ottaway, M. (1977). Land reform in Ethiopia 1974-1977. African Studies Review 20(3), 79-90.

Shiferaw Bekele (1995). An economic history of Ethiopia: the Imperial era 1941-1974. Codesria.

Shwab, P. (1970). The tax system of Ethiopia. The American Journal of Economics and Sociology 29(1), 77-88.

Vestal, T. M. (2011). The lion of Judah in the new world: Emperor Haile Selassie of Ethiopia and the shaping of America's attitudes toward Africa. ABC-CLIO.

Wubneh, M. (1990). State control and manufacturing labor productivity in Ethiopia. The journal of developing areas $24(3), 311-326$.

Young, J. (1997). Peasant revolution in Ethiopia: the Tigray People's Liberation Front 19751991. Cambridge University Press. 


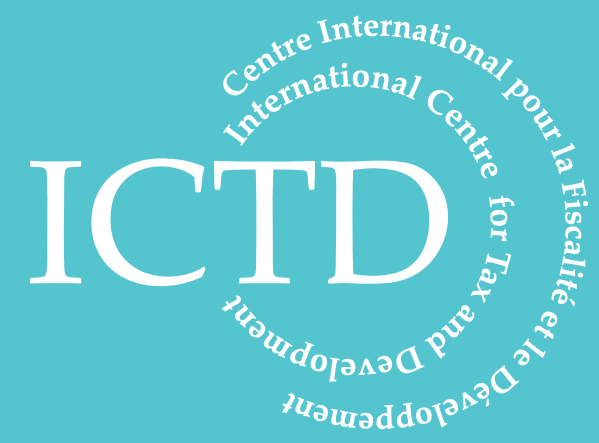

International Centre for Tax and Development at the Institute of Development Studies

Brighton BN1 9RE, UK

T: +44 (0) 1273606261

F: $+44(0) 1273621202$

E: info@ictd.ac

www.ictd.ac 